\title{
Marine isoprene production and consumption in the mixed layer of the surface ocean - a field study over two oceanic regions
}

\author{
Dennis Booge ${ }^{1}$, Cathleen Schlundt ${ }^{2}$, Astrid Bracher ${ }^{3,4}$, Sonja Endres ${ }^{1}$, Birthe Zäncker ${ }^{1}$, and Christa A. Marandino ${ }^{2}$ \\ ${ }^{1}$ GEOMAR Helmholtz Centre for Ocean Research, Kiel, Germany \\ ${ }^{2}$ Marine Biological Laboratory, MBL, Woods Hole, MA, USA \\ ${ }^{3}$ Alfred Wegener Institute - Helmholtz Centre for Polar and Marine Research, Bremerhaven, Germany \\ ${ }^{4}$ Institute of Environmental Physics, University of Bremen, Germany
}

Correspondence: Dennis Booge (dbooge@geomar.de)

Received: 21 June 2017 - Discussion started: 29 June 2017

Revised: 24 November 2017 - Accepted: 9 December 2017 - Published: 1 February 2018

\begin{abstract}
Parameterizations of surface ocean isoprene concentrations are numerous, despite the lack of source/sink process understanding. Here we present isoprene and related field measurements in the mixed layer from the Indian Ocean and the eastern Pacific Ocean to investigate the production and consumption rates in two contrasting regions, namely oligotrophic open ocean and the coastal upwelling region. Our data show that the ability of different phytoplankton functional types (PFTs) to produce isoprene seems to be mainly influenced by light, ocean temperature, and salinity. Our field measurements also demonstrate that nutrient availability seems to have a direct influence on the isoprene production. With the help of pigment data, we calculate in-field isoprene production rates for different PFTs under varying biogeochemical and physical conditions. Using these new calculated production rates, we demonstrate that an additional significant and variable loss, besides a known chemical loss and a loss due to air-sea gas exchange, is needed to explain the measured isoprene concentration. We hypothesize that this loss, with a lifetime for isoprene between 10 and 100 days depending on the ocean region, is potentially due to degradation or consumption by bacteria.
\end{abstract}

\section{Introduction}

Isoprene (2-methyl-1,3-butadiene, $\mathrm{C}_{5} \mathrm{H}_{8}$ ), a biogenic volatile organic compound (VOC), accounts for half of the total global biogenic VOCs in the atmosphere (Guenther et al., 2012). Globally, 400-600 $\mathrm{TgC}^{-1}$ is emitted from terres- trial vegetation (Guenther et al., 2006; Arneth et al., 2008). Emitted isoprene influences the oxidative capacity of the atmosphere and acts as a source for secondary organic aerosols (SOAs) (Carlton et al., 2009). It reacts with hydroxyl radicals $(\mathrm{OH})$, as well as ozone and nitrate radicals (Atkinson and Arey, 2003; Lelieveld et al., 2008), forming low-volatility species, such as methacrolein or methyl vinyl ketone, which are then further photooxidized to SOAs via more semivolatile intermediate products (Carlton et al., 2009). Model studies suggest that isoprene accounts for $27 \%$ (Hoyle et al., 2007), $48 \%$ (Henze and Seinfeld, 2006), or up to $79 \%$ (Heald et al., 2008) of the total SOA production globally.

Whereas the terrestrial isoprene emissions are well known to act as a source for SOAs, the oceanic source strength is hotly debated (Carlton et al., 2009). Marine-derived isoprene emissions only account for a few percent of the total emissions and are suggested, based on model studies, to be generally lower than $1 \mathrm{TgC}^{-1}$ (Palmer and Shaw, 2005; Arnold et al., 2009; Gantt et al., 2009; Booge et al., 2016). Some model studies suggest that these low emissions are not enough to control the formation of SOAs over the ocean (Spracklen et al., 2008; Arnold et al., 2009; Gantt et al., 2009; Anttila et al., 2010; Myriokefalitakis et al., 2010). However, due to its short atmospheric lifetime of minutes to a few hours, terrestrial isoprene does not reach the atmosphere over remote regions of the oceans. In these regions, oceanic emissions of isoprene could play an important role in SOA formation on regional and seasonal scales, especially in association with increased emissions during phytoplankton blooms ( $\mathrm{Hu}$ et al., 2013). In addition, the isoprene SOA yield could be 
up to $29 \%$ under acid-catalyzed particle phase reactions during low- $\mathrm{NO}_{x}$ conditions, which occur over the open oceans (Surratt et al., 2010). This SOA yield is significantly higher than a SOA burden of $2 \%$ during neutral aerosol experiments calculated by Henze and Seinfeld (2006).

Marine isoprene is produced by phytoplankton in the euphotic zone of the oceans, but only a few studies have directly measured the concentration of isoprene to date, and the exact mechanism of isoprene production is not known. The concentrations generally range between $<1$ and $200 \mathrm{pmolL}^{-1}$ (Bonsang et al., 1992; Milne et al., 1995; Broadgate et al., 1997; Baker et al., 2000; Matsunaga et al., 2002; Broadgate et al., 2004; Kurihara et al., 2010; Zindler et al., 2014; Ooki et al., 2015; Hackenberg et al., 2017). Depending on region and season, concentrations of isoprene in surface waters can reach up to 395 and $541 \mathrm{pmol} \mathrm{L}^{-1}$ during phytoplankton blooms in the highly productive Southern Ocean and Arctic waters, respectively (Kameyama et al., 2014; Tran et al., 2013).

Studies have shown that the depth profile of isoprene mainly follows the chlorophyll $a$ (chl $a$ ) profile, suggesting phytoplankton as an important source (Bonsang et al., 1992; Milne et al., 1995; Tran et al., 2013; Hackenberg et al., 2017); furthermore, Broadgate et al. (1997) and Kurihara et al. (2010) show a direct correlation between isoprene and chl $a$ concentrations in surface waters and between 5 and $100 \mathrm{~m}$ depth, respectively. However, this link is not consistent enough on global scales to predict marine isoprene concentrations using chl $a$ (Table 1). Laboratory studies with different monocultures illustrate that the isoprene production rate varies widely depending on the phytoplankton functional type (PFT) (Booge et al., 2016, and references therein). In addition, environmental parameters, such as temperature and light, have been shown to influence isoprene production (Shaw et al., 2003; Exton et al., 2013; Meskhidze et al., 2015). In general, the production rates increase with increasing light levels and higher temperature, similar to the terrestrial vegetation (Guenther et al., 1991). However, this trend cannot easily be generalized to all species, because each species-specific growth requirement is linked differently to the environmental conditions. For example, Srikanta Dani et al. (2017) showed that two diatom species, Chaetoceros calcitrans and Phaeodactylum tricornutum, have their maximum isoprene production rate at light levels of 600 and $200 \mu \mathrm{mol} \mathrm{m}^{-2} \mathrm{~s}^{-1}$, respectively, which decreases at even higher light levels. Furthermore, Meskhidze et al. (2015) measured the isoprene production rates of different diatoms at different temperature and light levels on two consecutive days. Their results showed a less variable but higher emission on day two, suggesting that phytoplankton must acclimate physiologically to the environment. This should also hold true for dynamic regions of the ocean and has to be taken into account when using field data to model isoprene production.
The main loss of isoprene in seawater is air-sea gas exchange, with a minor physical loss due to advective mixing and chemical loss by reaction with $\mathrm{OH}$ and singlet oxygen (Palmer and Shaw, 2005). The existence of biological losses still remains an open question, as almost no studies were conducted concerning this issue. Shaw et al. (2003) assumed the biological loss by bacterial degradation to be very small. However, Acuña Alvarez et al. (2009) showed that isoprene consumption in culture experiments from marine and coastal environments did not exhibit first-order dependency on isoprene concentration. They observed faster isoprene consumption with lower initial isoprene concentration.

This study significantly increases the small dataset of marine isoprene measurements in the world oceans with new observations of the distribution of isoprene in the surface mixed layer of the oligotrophic subtropical Indian Ocean and in the nutrient-rich upwelling area of the eastern $\mathrm{Pa}$ cific Ocean along the Peruvian coast. These two contrasting and, in terms of isoprene measurements, highly undersampled ocean basins are interesting regions in which to compare the diversity of isoprene-producing species. With the help of concurrently measured physical (temperature, salinity, radiation), chemical (nutrients, oxygen), and biological (pigments, bacteria) parameters, we aim to improve the understanding of isoprene production and consumption processes in the surface ocean under different environmental conditions.

\section{Methods}

\subsection{Sampling sites}

Measurements of oceanic isoprene were performed during three separate cruises, the SPACES (Science Partnerships for the Assessment of Complex Earth System Processes) and OASIS (Organic very short lived substances and their AirSea exchange from the Indian Ocean to the Stratosphere) cruises in the Indian Ocean and the ASTRA-OMZ (Air-Sea interaction of TRAce elements in Oxygen Minimum Zones) cruise in the eastern Pacific Ocean. The SPACES and OASIS cruises took place in July/August 2014 on board the R/V Sonne I from Durban, South Africa, via Port Louis, Mauritius, to Malé, Maldives; the ASTRA-OMZ cruise took place in October 2015 on board the R/V Sonne II from Guayaquil, Ecuador, to Antofagasta, Chile (Fig. 1).

\subsection{Isoprene measurements}

During all cruises, up to seven samples $(50 \mathrm{~mL})$ from 5 to $150 \mathrm{~m}$ depth for each depth profile were taken bubble-free from a $24 \mathrm{~L}$ Niskin bottle rosette equipped with a CTD (conductivity-temperature-depth; described in Stramma et al., 2016). Ten milliliters of helium was put into each transparent glass vial (Chromatographie Handel Müller, Fridolfing, Germany), replacing the same amount 
Table 1. Factors of different regression equations ([isoprene] $=u \times[$ chl $a]+v \times \mathrm{SST}+$ intercept) from different studies compared to factors from this study. Bold, italic, and regular $R^{2}$ value: correlation significant, not significant, and significance not known, respectively (significant: $p<0.05$ ). [chl $a$ ] in $\mu \mathrm{g} \mathrm{L}^{-1}$, $\mathrm{SST}$ in ${ }^{\circ} \mathrm{C}$, [isoprene] in $\mathrm{pmol} \mathrm{L} \mathrm{L}^{-1}$.

\begin{tabular}{|c|c|c|c|c|c|c|}
\hline Reference & Cruise (region) & SST bins & $u$ & $v$ & Intercept & $R^{2}$ \\
\hline \multirow[t]{5}{*}{ Hackenberg et al. (2017) } & AMT 22 (Atlantic O.) & \multirow[t]{3}{*}{$<20^{\circ} \mathrm{C}$} & 37.9 & - & 17.5 & $\mathbf{0 . 3 7}(n=39)$ \\
\hline & AMT 23 (Atlantic O.) & & 15.1 & - & 18.4 & $0.55(n=11)$ \\
\hline & ACCACIA 2 (Arctic) & & 34.1 & - & 11.1 & $\mathbf{0 . 6 1}(n=34)$ \\
\hline & AMT 22 (Atlantic O.) & \multirow[t]{2}{*}{$\geq 20^{\circ} \mathrm{C}$} & 300 & - & -3.35 & $\mathbf{0 . 6 0}(n=93)$ \\
\hline & AMT 23 (Atlantic O.) & & 103 & - & 5.58 & $\mathbf{0 . 8 2}(n=22)$ \\
\hline \multirow[t]{3}{*}{ Ooki et al. (2015) } & \multirow{3}{*}{$\begin{array}{l}\text { Southern Ocean, Indian } \\
\text { Ocean, Northwest Pacific } \\
\text { Ocean, Bering Sea, western } \\
\text { Arctic Ocean }\end{array}$} & $3.3-17^{\circ} \mathrm{C}$ & 14.3 & 2.27 & 2.83 & 0.64 \\
\hline & & $17-27^{\circ} \mathrm{C}$ & 20.9 & -1.92 & 63.1 & 0.77 \\
\hline & & $>27^{\circ} \mathrm{C}$ & 319 & 8.55 & -244 & 0.75 \\
\hline Kurihara et al. (2012) & Sagami Bay & No bin & 10.7 & - & 5.9 & $0.49(n=8)$ \\
\hline Kurihara et al. (2010) & Western North Pacific & No bin & 18.8 & - & 6.1 & $\mathbf{0 . 7 9}(n=60)$ \\
\hline Broadgate et al. (1997) & North Sea & No bin & 6.4 & - & 1.2 & 0.62 \\
\hline \multirow[t]{10}{*}{ This study } & \multirow{10}{*}{$\begin{array}{l}\text { Whole study } \\
\text { SPACES (Indian Ocean) } \\
\text { OASIS (Indian Ocean) } \\
\text { ASTRA-OMZ (eastern } \\
\text { South Pacific O.) }\end{array}$} & \multirow[t]{5}{*}{ No bin } & 2.45 & - & 22.1 & $\mathbf{0 . 0 7}(n=138)$ \\
\hline & & & 20.2 & - & 8.01 & $\mathbf{0 . 3 0}(n=37)$ \\
\hline & & & 42.6 & - & 12.6 & $\boldsymbol{0 . 1 0}(n=59)$ \\
\hline & & & 1.26 & - & 26.5 & $0.07(n=42)$ \\
\hline & & & & & & \\
\hline & & $<20^{\circ} \mathrm{C}$ & 3.92 & - & 11.5 & $\mathbf{0 . 5 9}(n=46)$ \\
\hline & & $\geq 20^{\circ} \mathrm{C}$ & 25.6 & - & 16.6 & $\mathbf{0 . 1 4}(n=92)$ \\
\hline & & $3.3-17^{\circ} \mathrm{C}$ & 1.30 & 10.0 & -144 & $\mathbf{0 . 8 4}(n=10)$ \\
\hline & & $17-27^{\circ} \mathrm{C}$ & 10.4 & 0.76 & -3.70 & $\mathbf{0 . 4 1}(n=97)$ \\
\hline & & $>27^{\circ} \mathrm{C}$ & 40.4 & -0.58 & 39.7 & $0.17(n=31)$ \\
\hline
\end{tabular}

of sea water and providing a headspace for the upcoming analysis. The water samples were, if necessary, stored in the fridge and analyzed on board, within $1 \mathrm{~h}$ of collection, using a purge-and-trap system attached to a gas chromatographmass spectrometer (GC-MS; Agilent 7890A/Agilent 5975C; inert XL MSD with triple-axis detector) (Fig. 2). Isoprene was purged for $15 \mathrm{~min}$ from the water sample with helium $\left(70 \mathrm{~mL} \mathrm{~min}^{-1}\right)$ containing $500 \mu \mathrm{L}$ of gaseous deuterated isoprene (d5-isoprene) as an internal standard to account for possible sensitivity drift (Fig. 2: purge unit, load position). The gas stream was dried using potassium carbonate (SPACES and OASIS) or a Nafion ${ }^{\circledR}$ membrane dryer (Perma Pure; ASTRA-OMZ). $\mathrm{CO}_{2}$ - and hydrocarbon-free dry, pressurized air with a flow of $180 \mathrm{~mL} \mathrm{~min}^{-1}$ was used as counter flow in the Nafion ${ }^{\circledR}$ membrane dryer (Fig. 2: water removal). Before being injected into the GC (Fig. 2: trap unit, inject position), isoprene was preconcentrated in a Sulfinert ${ }^{\circledR}$ stainless-steel trap (1/16 in. OD) cooled with liquid nitrogen (Fig. 2: trap unit, load position). The mass spectrometer was operated in single-ion mode, quantifying isoprene and d5- isoprene using $m / z$ ratios of 67 and 68 , and 72 and 73 , respectively. In order to perform daily calibrations for quantification, gravimetrically prepared liquid isoprene standards in ethylene glycol were diluted in Milli-Q water and measured in the same way as the samples. The precision for isoprene measurements was $\pm 8 \%$.

\subsection{Nutrient measurements}

Micronutrient samples were taken on every cruise from the CTD bottles (covering all sampled depths). The samples from SPACES were stored in the fridge at $-20^{\circ} \mathrm{C}$ and measured during OASIS. Samples from OASIS and ASTRAOMZ were directly measured on board with a QuAAtro autoanalyzer (Seal Analytical). Nitrate was measured as nitrite following reduction on a cadmium coil. The precision of nitrate measurements was calculated to be $\pm 0.13 \mu \mathrm{molL}^{-1}$. 

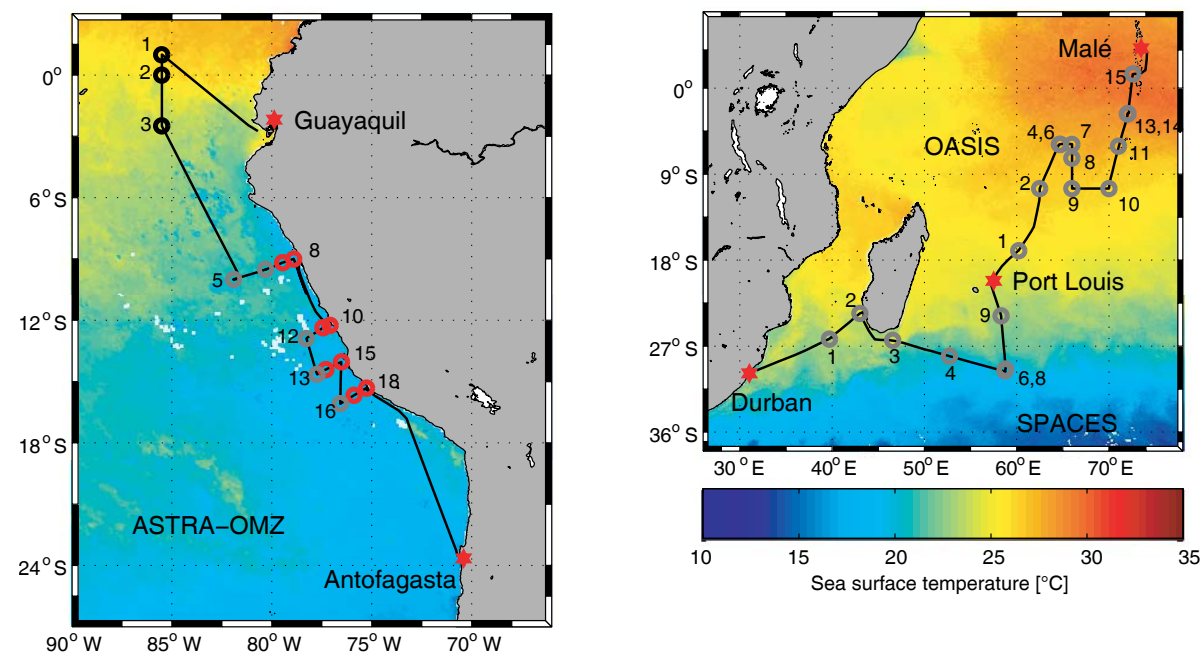

Figure 1. Cruise tracks (black) of ASTRA-OMZ (October 2015, eastern Pacific Ocean) and of SPACES and OASIS (July/August 2014, Indian Ocean) plotted on top of monthly mean sea surface temperature detected by the Moderate Resolution Imaging Spectroradiometer (MODIS) instrument on board the Aqua satellite. Circles indicate CTD stations (grey: SPACES and OASIS as well as open-ocean stations during ASTRA-OMZ; black: equatorial stations during ASTRA-OMZ; red: coastal stations during ASTRA-OMZ). Numbers indicate stations where a CTD depth profile was performed. Stations 6 and 8 (SPACES) as well as stations 4 and 6, and 13 and 14 (OASIS) have almost the same geographical coordinates. If a station number is omitted (SPACES: stations 5 and 7; OASIS: stations 3, 5, and 12; ASTRA-OMZ: stations 4 and 9), no CTD cast was performed.

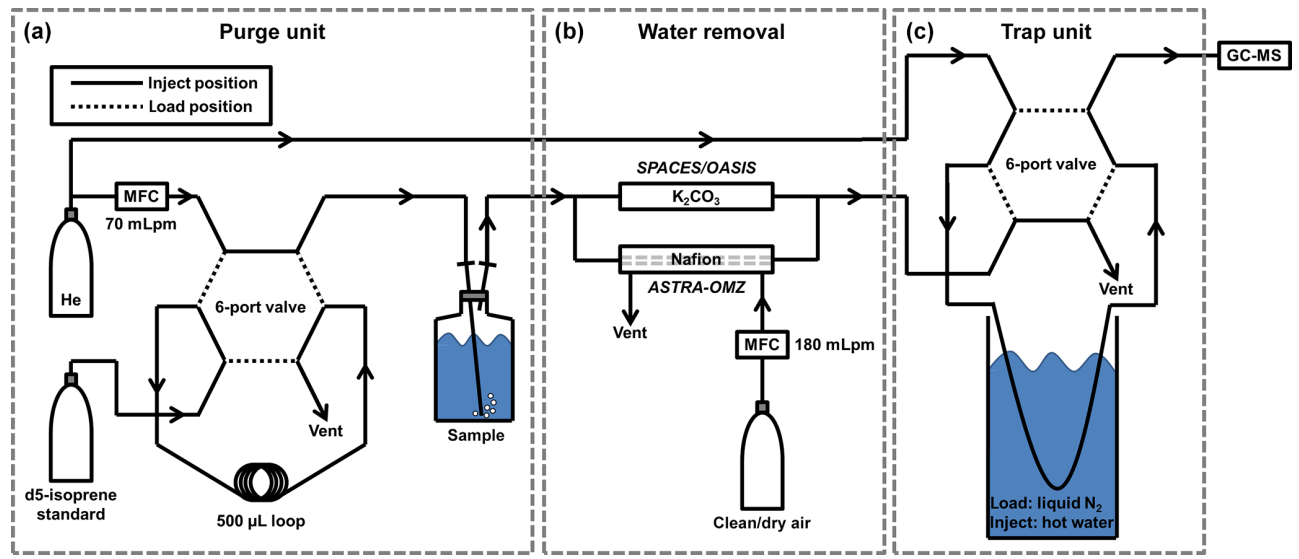

Figure 2. Schematic overview of the analytical purge-and-trap system, divided into three parts: purge unit (a), water removal (b), and trap unit (c). He: helium; MFC: mass flow controller; $\mathrm{K}_{2} \mathrm{CO}_{3}$ : potassium carbonate; GC-MS: gas chromatograph-mass spectrometer.

\subsection{Bacteria measurements}

For bacterial cell counts, $4 \mathrm{~mL}$ samples were preserved with $200 \mu \mathrm{L}$ glutaraldehyde (1\% v/v final concentration) and stored at $-20^{\circ} \mathrm{C}$ for up to 3 months until measurement. A stock solution of SYBR Green I (Invitrogen) was prepared by mixing $5 \mu \mathrm{L}$ of the dye with $245 \mu \mathrm{L}$ dimethyl sulfoxide (Sigma Aldrich). Ten microliters of the dye stock solution and $10 \mu \mathrm{L}$ of Fluoresbrite YG microspheres beads (diameter $0.94 \mu \mathrm{m}$, Polysciences) were added to $400 \mu \mathrm{L}$ of the thawed sample and incubated for $30 \mathrm{~min}$ in the dark. The samples were then analyzed at low flow rate using a flow cytome- ter (FACSCalibur, Becton Dickinson) (Gasol and Del Giorgio, 2000). Trucount beads (Becton Dickinson) were used for calibration and in combination with Fluoresbrite YG microsphere beads $(0.5-1 \mu \mathrm{m}$, Polysciences) for absolute volume calculation. Calculations were done using the software program "CellQuest Pro".

\subsection{Phytoplankton functional types from marker pigment measurements}

Different PFTs were derived from marker phytoplankton pigment concentrations and chlorophyll concentrations. To determine PFT chl $a, 0.5$ to $6 \mathrm{~L}$ of sea water was filtered 
through Whatman GF/F filters at the same stations where isoprene was sampled. The soluble organic pigment concentrations were determined using high-pressure liquid chromatography (HPLC) according to the method of Barlow et al. (1997), adjusted to our temperature-controlled instruments as detailed in Taylor et al. (2011). We determined the list of pigments shown in Table 2 of Taylor et al. (2011) and applied the method by Aiken et al. (2009) for quality control of the pigment data. PFT chl $a$ was calculated using the diagnostic pigment analysis developed by Vidussi et al. (2001) and adapted in Uitz et al. (2006). This method uses specific phytoplankton pigments which are (mostly) common only in one specific PFT. These pigments are called marker or diagnostic pigments (DPs), and the method relates for each measurement point the weighted sum of the concentration of seven DPs, representative of each PFT, to the concentration of monovinyl chlorophyll $a$ concentration; in doing so, PFT group-specific coefficients are derived which enable the PFT chl $a$ concentration to be derived. The latter is a ubiquitous pigment in all PFTs except Prochlorococcus, which contains divinyl chlorophyll $a$ instead. In general, chl $a$ is a valid proxy for the overall phytoplankton biomass. In the DP analysis, concentrations of fucoxanthin, peridinin, 19'hexanoyloxyfucoxanthin, 19'butanoyloxy-fucoxanthin, alloxanthin, and chlorophyll $b$ are used as DPs indicative of diatoms, dinoflagellates, haptophytes, chrysophytes, cryptophytes, cyanobacteria (excluding Prochlorococcus), and chlorophytes, respectively. With the DP analysis then finally the chl $a$ concentration of these PFTs were derived. The chl $a$ concentration of Prochlorococcus was directly derived from the concentration of divinyl chlorophyll $a$.

\subsection{Photosynthetically available radiation within the water column measurements}

Since no underwater light data were available for all cruises, we used global radiation data from the ship's meteorological station together with the light attenuation coefficients (determined from the chl $a$ concentration profiles) to calculate the photosynthetically available radiation (PAR) within the water column during a day. In detail we processed these data the following way.

We fitted the hourly resolved global radiation data with a sine function to account for the light variation during the day and converted into PAR just above surface, $\operatorname{PAR}\left(0^{+}\right)$ in $\mu \mathrm{mol} \mathrm{m} \mathrm{m}^{-2} \mathrm{~s}^{-1}$ during the course of a day, by multiplying these daily global radiation values with a factor of 2 (Jacovides et al., 2004) (Fig. S1a).

The subsurface PAR $\left(\operatorname{PAR}\left(0^{-}\right)\right)$was calculated using the refractive index of water $(n=1.34)$ and 0.98 for transmission assuming incident light angles $<49^{\circ}$ :

$\operatorname{PAR}\left(0^{-}\right)=E_{\mathrm{d}} \operatorname{PAR}\left(0^{+}\right) \times 1.34^{2} / 0.98$
In order to derive the diffuse attenuation coefficient for PAR $\left(K_{\mathrm{d}} \mathrm{PAR}\right)$, we calculated the euphotic depth $\left(Z_{\mathrm{eu}}\right)$ from the chl $a$ profile for all stations using the approximation by Morel and Berthon (1989), which was further refined by Morel and Maritorena (2001). In detail the following was done: from the chl $a$ profiles at each station the total chl $a$ integrated for $Z_{\text {eu }}\left(C_{\text {tot }}\right)$ was determined. A given profile was progressively integrated with respect to increasing depth $(z)$. The successive integrated chl $a$ values were introduced in Eqs. (2) and (3) accordingly, thus providing successive $Z_{\text {eu }}$ values that were progressively decreasing. Once the last $Z_{\mathrm{eu}}$ value, as obtained, became lower than the actual depth $z$ used when integrating the profile, these $C_{\text {tot }}$ and $Z_{\mathrm{eu}}$ values from the last integration were taken. Profiles which did not reach $Z_{\mathrm{eu}}$ were excluded.

$$
\begin{aligned}
& Z_{\mathrm{eu}}=912.5 \times C_{\mathrm{tot}}^{-0.839} ; \text { if } 10 \mathrm{~m}<Z_{\mathrm{eu}}<102 \mathrm{~m} \\
& Z_{\mathrm{eu}}=426.3 \times C_{\mathrm{tot}}^{-0.547} ; \text { if } Z_{\mathrm{eu}}>102 \mathrm{~m}
\end{aligned}
$$

$K_{\mathrm{d}} \mathrm{PAR}$ of each station was then calculated from $Z_{\mathrm{eu}}$ as follows:

$K_{\mathrm{d}} \mathrm{PAR}=\frac{4.6}{Z_{\mathrm{eu}}}$.

The plane photosynthetically available irradiance at each depth $(z)$ in the water column, $\operatorname{PAR}(z)$, was then calculated applying Beer-Lambert's law (Fig. S1b):

$\operatorname{PAR}(z)=\operatorname{PAR}_{\text {surface }} \times e^{-K_{\mathrm{d}} z}$.

An example of two PAR fitted depth profiles for the time of the two specific stations is shown in the Supplement (Fig. S2), which have been compared to directly measured downwelling photosynthetically available radiation $\left(E_{\mathrm{d}} \mathrm{PAR}\right)$ profiles. The comparison shows that the fitted PAR profiles obtained from the ship's global radiation data and chlorophyll profiles were reliable.

$E_{\mathrm{d}}$ PAR profiles were only measured during ASTRA daytime stations with a hyperspectral radiometer (RAMSES, TriOS GmbH, Germany) covering a wavelength range of 320 to $950 \mathrm{~nm}$ with an optical resolution of $3.3 \mathrm{~nm}$ and a spectral accuracy of $0.3 \mathrm{~nm}$ (for more details on the measurements see Taylor et al., 2011). The downwelling irradiance $E_{\mathrm{d}}(z, \lambda)$ RAMSES data were interpolated to $1 \mathrm{~nm}$ resolution, and then the $E_{\mathrm{d}}(z)$ given in watts per square meter $\left(\mathrm{W} \mathrm{m}^{-2}\right)$ at each nanometer wavelength step between 400 and $700 \mathrm{~nm}$ was converted to micromolar quanta per square meter per second ( $\mu$ mol quanta $\mathrm{m}^{-2} \mathrm{~s}^{-1}$ ) to micromolar quanta per square by following the principle that one photon contains the energy $E_{\mathrm{p}}=(h \times c) / \lambda$ (with the Planck's constant $h=6.6266 \times$ $10^{-34} \mathrm{Js}$ and the speed of light $c=299792458 \mathrm{~m} \mathrm{~s}^{-1}$ ). Finally, the $E_{\mathrm{d}}(z, \lambda)$ were integrated from 400 to $700 \mathrm{~nm}$ to receive the downwelling photosynthetically available plane irradiance $\left(E_{\mathrm{d}} \operatorname{PAR}(z)\right)$. 
Table 2. Emission factor (EF) of each PFT determined by applying a log-squared relationship between light intensity and isoprene production rates resulting from published phytoplankton culture experiments.

\begin{tabular}{lll}
\hline PFT & Emission factor & References of literature values used for fitting ${ }^{\mathrm{a}}$ \\
\hline Diatoms & 0.0064 & Shaw et al. (2003), Bonsang et al. (2010), Exton et al. (2013), Meskhidze et al. (2015) \\
Chlorophytes & 0.0168 & Shaw et al. (2003), Bonsang et al. (2010), Exton et al. (2013) \\
Dinoflagellates & 0.0176 & Exton et al. (2013) \\
Haptophytes & 0.0099 & Shaw et al. (2003), Bonsang et al. (2010), Exton et al. (2013) \\
Cyanobacteria & 0.0097 & Shaw et al. (2003), Bonsang et al. (2010), Exton et al. (2013) \\
Cryptophytes & 0.0120 & Exton et al. (2013) \\
Prochlorococcus & 0.0053 & Shaw et al. (2003) \\
\hline
\end{tabular}

${ }^{a}$ Exact species within a PFT tested for calculation production rates can be found in the references cited for each PFT.

\subsection{Calculation of isoprene production}

We calculated the isoprene production rate $(P)$ in two different ways: a direct and an indirect calculation, which will be explained in the following paragraphs. For all calculations made, we came up with one production rate per station within the mixed layer. This was either due to the shallow mixedlayer depth (MLD) resulting in only one measurement within the mixed layer (coastal stations ASTRA-OMZ) or due to well-mixed isoprene concentrations showing almost no gradient within the mixed layer (data explained in Sect. 3.2).

\subsubsection{Direct calculation of isoprene production rates}

Isoprene production rates of different PFTs were determined in laboratory phytoplankton culture experiments (see a collection of literature values: Table 2 in Booge et al., 2016) and were used here to calculate isoprene production from measured PFTs in the field. These literature studies showed that isoprene production rates are light dependent, with increasing production rates at higher light levels (Shaw et al., 2003; Gantt et al., 2009; Bonsang et al., 2010; Meskhidze et al., 2015). To include the light dependency in our calculations, we followed the approach of Gantt et al. (2009) for each PFT by applying a log-squared fit between all single literature laboratory chl- $a$-normalized isoprene production rates $P_{\text {chloro }}$ $\left(\mu \mathrm{mol}\right.$ isoprene $\left.(\mathrm{g} \mathrm{chl} a)^{-1} \mathrm{~h}^{-1}\right)$ (references in Table 2) and their measured light intensity $I\left(\mu \mathrm{mol} \mathrm{m}{ }^{-2} \mathrm{~s}^{-1}\right)$ during individual experiments to determine an emission factor (EF) for each PFT (Fig. S3):

$P_{\text {chloro }}=\mathrm{EF} \times \ln (I)^{2}$.

The resulting EF from this log-squared fit is unique for each PFT and is listed in Table 2: the higher the EF of a PFT, the higher its $P_{\text {chloro }}$ value at a specific light intensity. It should be noted that we are not sure what species were actually present during the cruises. We realize, therefore, that this method of calculating EFs is limited. In order to calculate the isoprene production at each sampled depth $(z)$ at each station, we used the scalar photosynthetically available radiation in the water column, $\operatorname{PAR}(z)$ (see Sect. 2.6), as input for $I$, which was used with the respective calculated $\mathrm{EF}$ of each PFT using Eq. (6). The product was integrated over the course of the day, resulting in a $P_{\text {chloro }}$ value $(\mu \mathrm{mol}$ isoprene $(\mathrm{g} \mathrm{chl} a)^{-1}$ day $\left.^{-1}\right)$ for each PFT and day depending on the depth in the water column (Fig. S4). The light- and depth-dependent individual $P_{\text {chloro, } i}$ values of each PFT at the sampled depth $z$ were multiplied with the corresponding measured PFT chl $a$ concentration $\left([\mathrm{PFT}]_{i}\right)$. The sum of all products gives the directly calculated isoprene production rate at each sampled depth $z$ :

$P_{\text {direct }}(z)=\sum\left(P_{\text {chloro }_{i}} \times[\mathrm{PFT}]_{i}\right)$.

Integrating over all measurements within the mixed layer and scaling with the MLD results in a "mean" direct isoprene production rate $\left(\mathrm{P}_{\text {direct }}\right)$ for each station.

\subsubsection{Indirect calculation of isoprene production rates}

The indirect calculation of the isoprene production rate is dependent on our measured isoprene concentrations $\left(C_{\text {Wmeasured }}\right)$. We used the simple model concept of Palmer and Shaw (2005), assuming that the measured isoprene concentration is in steady state, meaning that the production $(P)$ is balanced by all loss processes:

$$
\begin{aligned}
& P-C_{\mathrm{Wmeasured}}\left(\sum k_{\mathrm{CHEM}, i} C_{\mathrm{Xi}}+k_{\mathrm{BIOL}}+\frac{k_{\mathrm{AS}}}{\mathrm{MLD}}\right) \\
& -L_{\mathrm{MIX}}=0,
\end{aligned}
$$

where $k_{\text {CHEM }}$ is the chemical loss rate constant for all possible loss pathways $(i)$ with the concentrations of the reactants $\left(C_{X}=\mathrm{OH}\right.$ and $\left.\mathrm{O}_{2}\right), k_{\mathrm{BIOL}}$ is the biological loss rate constant due to biological degradation, and $L_{\mathrm{MIX}}$ is the loss due to physical mixing. These constants are further described in Palmer and Shaw (2005). $k_{\mathrm{AS}}$ is the loss rate constant due to air-sea gas exchange scaled with the MLD. The MLD at each station was calculated from CTD profile measurements, applying the temperature threshold criterion $\left( \pm 0.2^{\circ} \mathrm{C}\right)$ of de Boyer Montégut et al. (2004). $k_{\mathrm{AS}}$ was computed using the 
Schmidt number $\left(S_{\mathrm{C}}\right)$ of isoprene (Palmer and Shaw, 2005) and the quadratic wind-speed-based $\left(U_{10}\right)$ parameterization of Wanninkhof (1992):

$k_{\mathrm{AS}}=0.31 U_{10}^{2}\left(\frac{S_{\mathrm{C}}}{660}\right)^{-0.5}$

As we assume steady-state isoprene concentration, we used the mean wind speed and the mean sea surface temperature (SST) of the last $24 \mathrm{~h}$ of shipboard observations before taking the isoprene sample to calculate $U_{10}$ and $S_{\mathrm{C}}$, respectively.

We modified Eq. (8) to calculate the needed production rate $\left(P_{\text {need }}\right)$ by multiplying $C_{\text {Wmeasured with the sum of }}$ $k_{\mathrm{CHEM}}\left(0.0527\right.$ day $\left.^{-1}\right)$ and $k_{\mathrm{AS}}$ scaled with the MLD:

$P_{\text {need }}=C_{\text {Wmeasured }}\left(k_{\mathrm{CHEM}}+\frac{k_{\mathrm{AS}}}{\mathrm{MLD}}\right)$.

We neglected the loss rates of isoprene due to biological degradation and physical mixing because they are low compared to $k_{\mathrm{CHEM}}$ and $k_{\mathrm{AS}}$ (Palmer and Shaw, 2005; Booge et al., 2016), meaning that the resulting $P_{\text {need }}$ value can be seen as a minimum needed production rate.

\section{Results and discussion}

\subsection{Cruise settings}

The first part of the Indian Ocean cruise, SPACES, started in Durban and traveled eastwards, passing the Agulhas current and the southern tip of Madagascar (Toliara reef) with relatively warm water masses (mean: $23.4^{\circ} \mathrm{C}$ ) and southerly winds. Southeast of Madagascar wind direction changed to easterly winds, and we encountered the Antarctic circumpolar current with significantly lower mean sea surface temperatures of $19.7^{\circ} \mathrm{C}$ before heading north to Mauritius. Mean wind speed during the cruise was $8.2 \pm 3.7 \mathrm{~m} \mathrm{~s}^{-1}$, and mean salinity was $35.5 \pm 0.2$. Global radiation over the course of the day was on average $\sim 360 \pm 70 \mathrm{Wm}^{-2}$. As shown in Fig. 3, within the mixed layer, chl $a$ concentrations were very low (average value $<0.3 \mu \mathrm{gL}^{-1}$ ) during the whole cruise, coinciding with generally low nutrient levels in the mixed layer (mean values for nitrate and phosphate were 0.14 and $0.15 \mu \mathrm{mol} \mathrm{L}^{-1}$, respectively).

The second part of the Indian Ocean cruise, OASIS, covered open-ocean regimes and upwelling regions, such as the equatorial overturning cell as described in Schott et al. (2009) and the shallow Mascarene Plateau $\left(8-12^{\circ} \mathrm{S}, 59-62^{\circ} \mathrm{E}\right)$. Constant southeasterly winds (mean: $10.3 \pm 4.2 \mathrm{~m} \mathrm{~s}^{-1}$ ) were observed that were characteristic for the season of the southwest monsoon. During the cruise, sea surface temperature was constantly increasing with latitude from $24.4^{\circ} \mathrm{C}$ (Port Louis) to $29.7^{\circ} \mathrm{C}$ (southern tip of the Maldives) with mean daily light levels of $\sim 457 \pm 64 \mathrm{~W} \mathrm{~m}^{-2}$. Salinity ranged from 34.4 to 35.4 . As for the SPACES cruise, the chl $a$ concentration in the western tropical Indian Ocean was low $\left(0.2-0.5 \mu \mathrm{gL}^{-1}\right.$ on average, Fig. 3). Nitrate levels (mean: $0.42 \mu \mathrm{molL}^{-1}$ ) in the mixed layer were higher than during SPACES, but phosphate levels were not (mean: $0.17 \mu \mathrm{mol} \mathrm{L}^{-1}$ ).

The ASTRA-OMZ cruise took place in the coastal, winddriven Peruvian upwelling system $\left(16^{\circ} \mathrm{S}-6^{\circ} \mathrm{S}\right)$. This area is a part of one of the four major eastern boundary upwelling systems (Chavez and Messié, 2009) and is highly influenced by the El Niño-Southern Oscillation. We observed constant southeasterly winds $\left(8.2 \pm 2.5 \mathrm{~m} \mathrm{~s}^{-1}\right)$ traveling parallel to the Peruvian coast. During neutral surface conditions or La Niña conditions, cold, nutrient-rich water is being upwelled at the shelf of Peru, resulting in high biological productivity. However, in early 2015 a strong El Niño developed, which brought warmer, low-salinity waters from the western Pacific to the coast of Peru, resulting in suppressed upwelling with lower biological activity due to the presence of nutrientpoor water masses. The cruise started with a section passing the Equator from north to south at $85.5^{\circ} \mathrm{W}$ east of the Galapagos Islands with mean sea surface temperatures of $25.0^{\circ} \mathrm{C}$ and low-salinity waters (mean for profiles: 34.2 ), as well as low chl $a$ concentrations (mean for profiles: $0.5 \mu \mathrm{g} \mathrm{L}^{-1}$ ). Levels of incoming shortwave radiation were $\sim 508 \pm 67 \mathrm{~W} \mathrm{~m}^{-2}$. Afterwards, we performed four onshore-offshore transects at about $9,12,14$, and $16^{\circ} \mathrm{S}$ off the coast of Peru (Fig. 1), where the incoming shortwave radiation was significantly decreased by clouds $\left(\sim 300 \mathrm{~W} \mathrm{~m}^{-2}\right)$. Upwelled waters, identified by higher salinity (mean: 35.2 ) and lower sea surface temperatures (mean: $18.9^{\circ} \mathrm{C}$ ), were found during the second part of the cruise. Chl $a$ values were highest directly at the coast (max: $13.1 \mu \mathrm{g} \mathrm{L}{ }^{-1}$ ), coinciding with lower sea surface temperatures (Fig. 3), showing that some upwelling was still present.

\subsection{Isoprene distribution in the mixed layer}

The isoprene concentrations during the SPACES cruise were generally very low, ranging from 6.1 to $27.1 \mathrm{pmol} \mathrm{L}^{-1}$ in the mixed layer (mean for the average of a profile: $12.3 \mathrm{pmolL}^{-1}$ ) in the southern Indian Ocean, mainly due to very low biological productivity. During the OASIS cruise, the isoprene concentrations south of $10^{\circ} \mathrm{S}$ were comparable to the concentrations of the SPACES cruise. North of $10^{\circ} \mathrm{S}$, the isoprene values in the mixed layer were significantly higher (mean: 35.9 pmolL $^{-1}$ ) (Fig. 3). These results are in good agreement with the sea surface isoprene concentrations of Ooki et al. (2015) in the same area east of $60^{\circ} \mathrm{E}$, who measured concentrations lower than $20 \mathrm{pmol} \mathrm{L}^{-1}$ south of $12^{\circ} \mathrm{S}$ and concentrations of $\sim 40 \mathrm{pmol} \mathrm{L}^{-1}$ north of $12^{\circ} \mathrm{S}$ during a campaign between November 2009 and January 2010. During ASTRA-OMZ the concentrations ranged from 12.7 to $53.2 \mathrm{pmolL}^{-1}$ with a mean isoprene concen- 

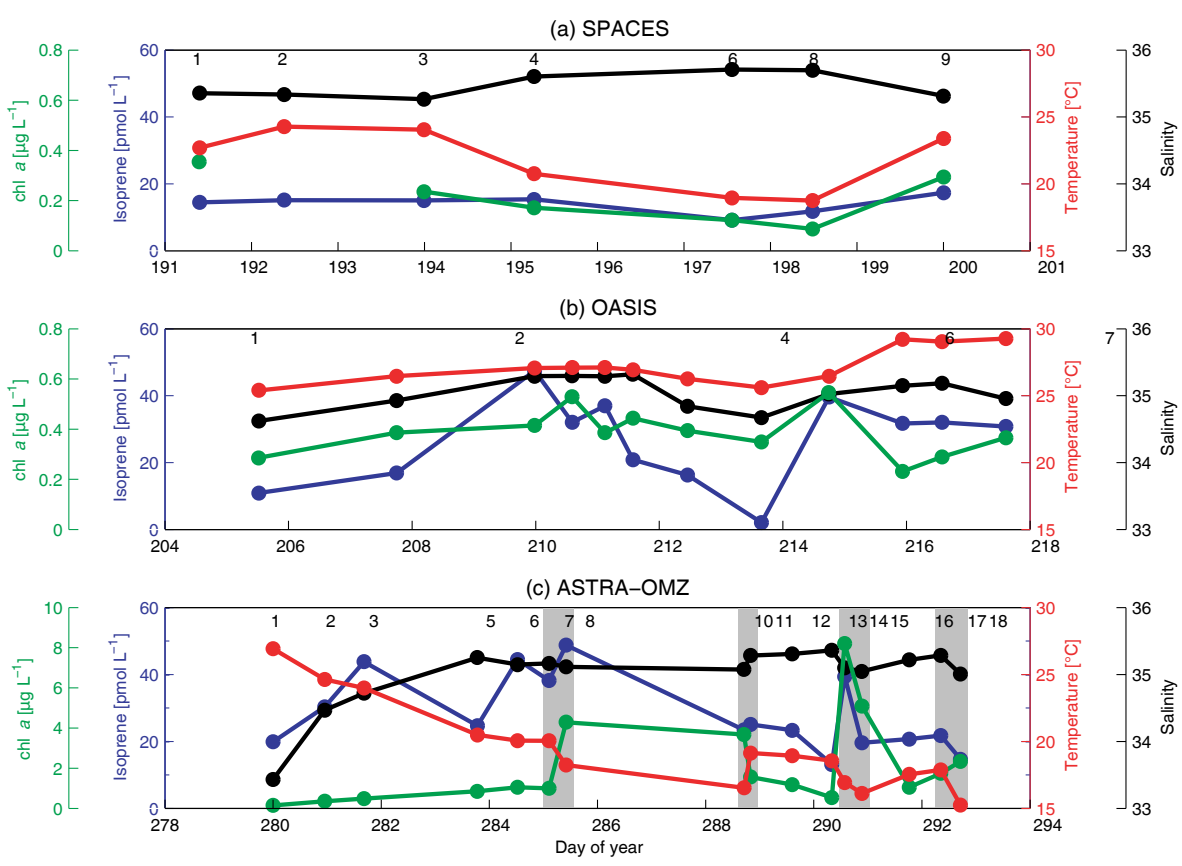

Figure 3. Mean salinity (black), isoprene concentration (blue), temperature (red), and chl $a$ concentration (green) in the MLD at each station during SPACES (a), OASIS (b), and ASTRA-OMZ (c). Grey rectangles highlight the eight coastal stations during ASTRA-OMZ. Numbers in each panel refer to the corresponding station number.

tration of $29.5 \mathrm{pmolL}^{-1}$ in the mixed layer. Although the chl $a$ concentrations at the coastal stations $\left(3.8 \mu \mathrm{g} \mathrm{L}^{-1}\right)$ were significantly higher than open-ocean values $\left(0.7 \mu \mathrm{gL}^{-1}\right)$, the isoprene values did not show the same trend (Fig. 3).

A mean normalized depth profile of each cruise for isoprene (blue), water temperature (black), oxygen (red), and chl $a$ (green) is shown in Fig. 4. In order to compare the depth profiles of each cruise with respect to the different concentration regimes, we normalized the measured values by dividing the concentration of each depth of each station by the mean concentration in the mixed layer from the same station profile. A normalized value $>1$ means that the value at a certain depth is higher than the mean value in the mixed layer; a value $<1$ means less than in the mixed layer. As the sampled depths at each station were not the same on every cruise, we binned the data into seven equally spaced depth intervals $(15 \mathrm{~m})$ and averaged each data of an interval over each of the three cruises. The calculated mean mixed-layer depths of the SPACES and OASIS cruises, using the temperature threshold criterion $\left( \pm 0.2^{\circ} \mathrm{C}\right)$ of de Boyer Montégut et al. (2004), were about $60 \mathrm{~m}$; the mean mixed-layer depth of the ASTRA-OMZ cruise was $30 \mathrm{~m}$, excluding the four coastal stations, which had a MLD of only $20 \mathrm{~m}$, resulting in only one bin interval in the MLD. Figure 4 shows that during all three cruises almost no gradient of isoprene in the mixed layer was detectable. In contrast to the isoprene concentration, the highest chl $a$ concentration was measured slightly above or below the MLD during SPACES/OASIS, whereas during ASTRA-OMZ chl $a$ showed the same trend as isoprene. These results suggest a very fast mixing of isoprene after it is produced by phytoplankton and released to the water column above the MLD.

As isoprene is produced biologically by phytoplankton, many studies have attempted to find a correlation between chl $a$ and isoprene, finding very different results. Bonsang et al. (1992), Milne et al. (1995), and Zindler et al. (2014) did not find a significant correlation, whereas other studies could show a significant correlation and, therefore, attempted a linear regression to show a relationship between isoprene and chl $a$, as well as SST (Broadgate et al., 1997; Kurihara et al., 2010, 2012; Ooki et al., 2015; Hackenberg et al., 2017). Comparing the different factors of each regression equation (Table 1), it can be seen that, even if the correlations for most of the datasets are significant, there is no globally unique regression factor to adequately describe the relationship between chl $a$ (and SST) and isoprene. As shown in Table 1, during ASTRA-OMZ there was no significant correlation between chl $a$ and isoprene, whereas during SPACES and OASIS the correlation was significant but with low $R^{2}$ values (SPACES: $R^{2}=0.30$; OASIS: $R^{2}=0.10$ ) and different regression coefficients. Hackenberg et al. (2017) split their data from three different cruises into two SST bins with SST values higher and lower than $20^{\circ} \mathrm{C}$, resulting in significant correlations with $R^{2}$ values from 0.37 to 0.82 depending on the cruise (Table 1). Ooki et al. (2015) described a multiple linear relationship between isoprene, $\operatorname{chl} a$, and SST when us- 


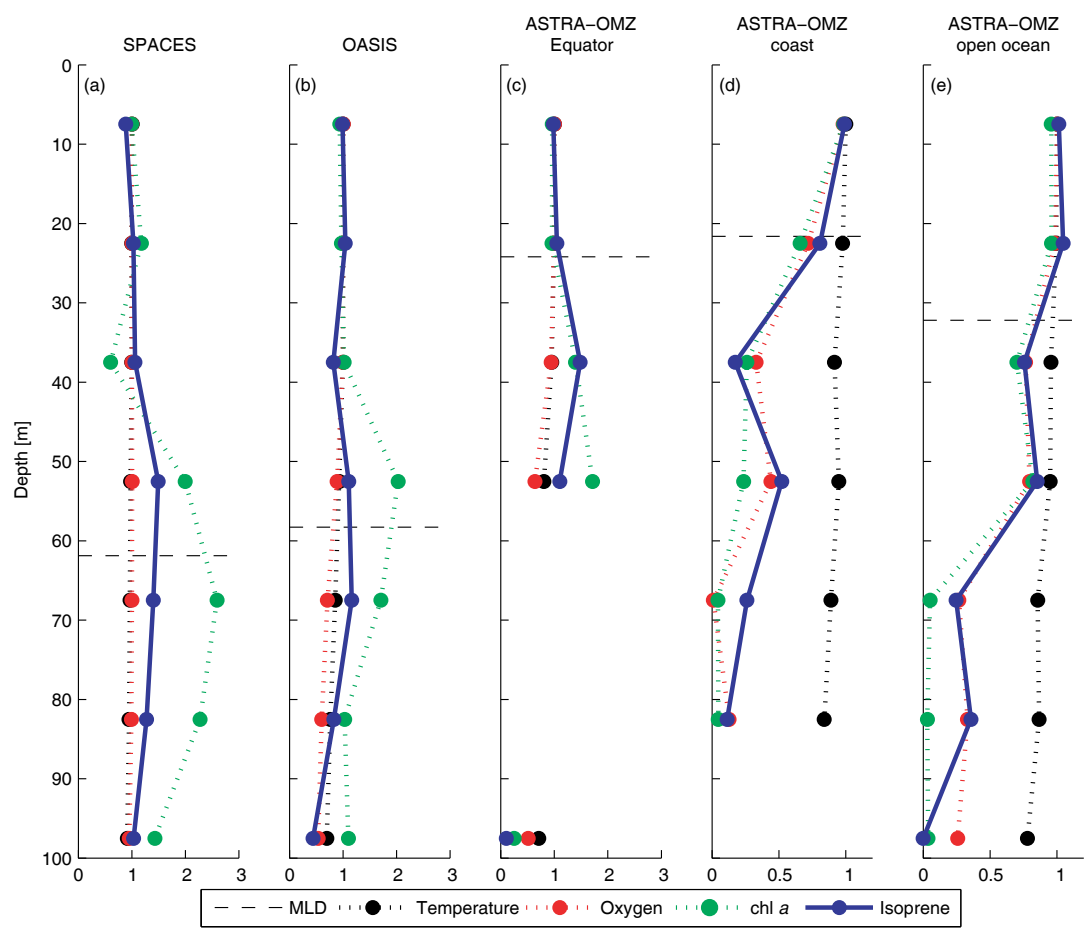

Figure 4. Mean normalized depth profiles of temperature (black), oxygen (red), chl $a$ (green), and isoprene (blue) during (a) SPACES, (b) OASIS, and (c, d,e) ASTRA-OMZ. The black dashed line represents the mean MLD for each cruise.

ing three different SST regimes (Table 1). Our correlations, using the approaches of Ooki et al. (2015) and Hackenberg et al. (2017), were significant, except for SST values higher than $27^{\circ} \mathrm{C}$, but the regression coefficients were also significantly different to those found by Ooki et al. (2015) and Hackenberg et al. (2017). These varying equations demonstrate that bulk chl $a$ concentrations, or linear combinations of chl $a$ concentration and SST, do not adequately predict the variability of isoprene in the global surface ocean, but they do point to these variables as among the main controls on isoprene concentration in the euphotic zone.

\subsection{Modeling chl- $a$-normalized isoprene production rates}

The directly calculated production rate $\left(P_{\text {direct }}\right)$ using Eq. (7) and the indirectly calculated production rate $\left(P_{\text {need }}\right)$ using Eq. (10) were compared and were found to be significantly different (Fig. 5a; difference in percent: $\left(P_{\text {direct }}-\right.$ $\left.\left.P_{\text {need }}\right) / P_{\text {need }} \times 100\right)$. The difference of more than $-70 \%$ between $P_{\text {direct }}$ and $P_{\text {need }}$ during SPACES and OASIS means that $P_{\text {direct }}$ is too low to account for the measured isoprene concentrations, which is also true for the equatorial region of ASTRA-OMZ. In the open-ocean region of ASTRA-OMZ, the average difference between $P_{\text {direct }}$ and $P_{\text {need }}$ is the lowest but still highly variable from station to station. However, in the coastal region of ASTRA-OMZ the directly calculated isoprene production rate greatly overestimates the needed production by $75 \%$ on average. There are three possible explanations for this difference: (1) the presence of a missing sink, which is not accounted for in the calculation of $P_{\text {need }}$. Adding an additional loss term to Eq. (10) would increase the needed production to reach the measured isoprene concentration. This sink would only be valid for this specific coastal region but would increase the discrepancy between $P_{\text {direct }}$ and $P_{\text {need }}$ for all other performed cruises. Furthermore, this possible loss rate constant would have to be on average 0.22 day $^{-1}$ and, therefore, higher than the main loss due to air-sea gas exchange in the coastal region (see Sect. 3.5 and Fig. 8). Thus, it is highly unlikely that this additional loss term is the only reason for the discrepancy between $P_{\text {direct }}$ and $P_{\text {need }}$. (2) Another possible explanation arises from the uncertainty of using a light-dependent log-squared fit. Measurements from different laboratory studies used different species within one group of PFTs. All species within one PFT group were combined to produce a light-dependent isoprene production rate (Fig. S3), although the isoprene production variability of different species within one PFT group is quite high. This will certainly influence $P_{\text {direct }}$ but cannot explain the $70 \%$ difference between $P_{\text {direct }}$ and $P_{\text {need }}$ measured during SPACES and OASIS and during ASTRA-OMZ (Equator) (Fig. 5). (3) An incorrect literature-derived chl- $a$ normalized isoprene production rate $\left(P_{\text {chloro }}\right)$ for one or more groups of PFTs is another possible explanation. For example, the high $P_{\text {direct }}$ values, compared to the $P_{\text {need }}$ values, during ASTRA-OMZ coincided with high chl $a$ concentrations in 
the coastal area. These coastal stations were, in contrast to all other measured stations, highly dominated by diatoms (up to $7.67 \mu \mathrm{g} \mathrm{L}^{-1}$, Fig. S5). This might point to a possibly incorrect

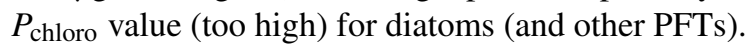

Therefore, we calculated new individual chl $a$ normalized production rates of each PFT ( $\left.P_{\text {chloronew }}\right)$ within the MLD. We used the concentrations of haptophytes, cyanobacteria, and Prochlorococcus for SPACES and OASIS and the concentrations of haptophytes, chlorophytes, and diatoms for ASTRA-OMZ, as these PFTs were the three most abundant PFTs of each cruise, accounting on average for $\geq 80 \%$ of total PFTs. We performed a multiple linear regression by fitting a linear equation between the $P_{\text {need }}$ values for each station and the corresponding PFT chl $a$ concentrations (analogous to Eq. 7) to derive one new calculated $P_{\text {chloronew }}$ value for each PFT and cruise, which is listed in Table 3. The lower and upper limit of the

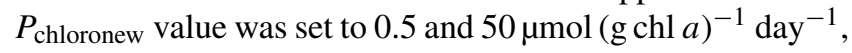
respectively, when performing the multiple linear regression to avoid mathematically possible but biologically unreasonable negative chl- $a$-normalized isoprene production rates. The upper limit was chosen in relation to the maximum published chl- $a$-normalized isoprene production rate of Prasinococcus capsulatus by Exton et al. (2013) (32.16 \pm $\left.5.76 \mu \mathrm{mol}(\mathrm{g} \mathrm{chl} a)^{-1} \mathrm{day}^{-1}\right)$. This rate was measured during common light levels of $300 \mu \mathrm{molm}^{-2} \mathrm{~s}^{-1}$. Applying a same log-squared relationship between light levels and the isoprene production rate as for the other PFTs would increase this value up to $50 \mu \mathrm{mol}(\mathrm{g} \operatorname{chl} a)^{-1} \mathrm{day}^{-1}$ at light levels of $\sim 1000 \mu \mathrm{mol} \mathrm{m}^{-2} \mathrm{~s}^{-1}$. Our tests using the whole PFT community for the multiple linear regression did not change our results and, in some cases, led to highly unlikely production rates for the less abundant PFTs.

With the help of the multiple-linear-regression-derived $P_{\text {chloronew values, we calculated the new direct isoprene pro- }}$ duction rate $\left(P_{\text {calc }}\right)$ in the same way as $P_{\text {direct }}$ in Eq. (7). We compared our calculated $P_{\text {calc }}$ values with the $P_{\text {need }}$ values which are shown in Fig. 5b (difference in percent between $P_{\text {calc }}$ and $\left.P_{\text {need }}\right)$. We found one outlier station for each cruise (SPACES: station 1; OASIS: station 10; ASTRA-OMZ: station 17) when using the new $P_{\text {chloronew values for each PFT }}$ for each whole cruise (Fig. 5b, left part). We excluded these stations from every following calculation and redid the multiple linear regression. Furthermore, we split the ASTRAOMZ into three different regions (Equator, coast, and open ocean), due to their contrasting biomass-to-isoprene concentration ratio, and calculated new $P_{\text {chloronew }}$ values for each of the three most abundant PFTs for SPACES, OASIS, and each part of ASTRA-OMZ.

Haptophytes were one of the three most abundant PFTs during all three cruises (Fig. S5), and their $P_{\text {chloronew val- }}$ ues range from 0.5 to $47.9 \mu \mathrm{mol}(\mathrm{g} \mathrm{chl} a)^{-1}$ day $^{-1}$ with a mean value of $17.9 \pm 18.3 \mu \mathrm{mol}(\mathrm{g} \mathrm{chl} a)^{-1} \mathrm{day}^{-1}$ for all cruises. The haptophyte production rates exhibited two interesting features. First, this range is highly variable depend- ing on the oceanic region (tropical ocean (SPACES), subtropical ocean (OASIS)) and different ocean regimes (coast, open ocean). Second, the average value is different from the mean value of all laboratory-study-derived isoprene production rates of haptophytes $\left(6.92 \pm 5.78 \mu \mathrm{mol}(\mathrm{g} \mathrm{chl} a)^{-1} \mathrm{day}^{-1}\right.$, Table 3). During SPACES and OASIS the $P_{\text {chloronew }}$ values of Prochlorococcus (both $0.5 \mu \mathrm{mol}(\mathrm{g} \mathrm{chl} a)^{-1} \mathrm{day}^{-1}$ ) are slightly lower but in good agreement with the mean literature value $\left(1.5 \mu \mathrm{mol}(\mathrm{gchl} a)^{-1} \mathrm{day}^{-1}\right.$, Table 3), whereas the cyanobacteria values are higher (44.7 and $\left.13.9 \mu \mathrm{mol}(\mathrm{g} \mathrm{chl} a)^{-1} \mathrm{day}^{-1}\right)$ than the literature value $\left(6.04 \mu \mathrm{mol}(\mathrm{g} \mathrm{chl} a)^{-1} \mathrm{day}^{-1}\right.$, Table 3). Chlorophytes and are known to be low isoprene producers, with

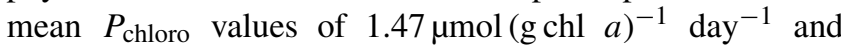
$2.51 \mu \mathrm{mol}(\mathrm{g} \mathrm{chl} a)^{-1} \mathrm{day}^{-1}$, respectively (Table 3 ). For diatoms, this is verified with our calculated rates during ASTRA-OMZ (all values $\leq 0.6 \mu \mathrm{mol}(\mathrm{gchl} a)^{-1}$ day $\left.^{-1}\right)$, whereas the rate for chlorophytes in the coastal regions $\left(6.1 \mu \mathrm{mol}(\mathrm{g} \mathrm{chl} a)^{-1} \mathrm{day}^{-1}\right)$ is significantly higher than in the open ocean and equatorial region during ASTRA-OMZ $\left(0.5 \mu \mathrm{mol}(\mathrm{g} \mathrm{chl} a)^{-1} \mathrm{day}^{-1}\right)$. Over all three cruises no significant correlations were found between the new multiplelinear-regression-derived $P_{\text {chloronew }}$ values of each PFT and any other parameter measured on the cruise. This may be caused by the high variability of the chl $a$ normalized production rates of different PFTs (Table 3). Another explanation could be the high variability of isoprene production of different species within one PFT group. For instance, in the PFT group of haptophytes, the isoprene production rates of two different strains of Emiliania huxleyi measured by Exton et al. (2013) were $11.28 \pm 0.96$ and $2.88 \pm 0.48 \mu \mathrm{mol}(\mathrm{g} \mathrm{chl} a)^{-1} \mathrm{day}^{-1}$ for strain CCMP 1516 and CCMP 373, respectively. Laboratory culture experiments show that stress factors, like temperature and light, also influence the emission rate within one species (Shaw et al., 2003; Exton et al., 2013; Meskhidze et al., 2015). Srikanta Dani et al. (2017) showed that in a light regime of 100 $600 \mu \mathrm{mol} \mathrm{m} \mathrm{m}^{-2} \mathrm{~s}^{-1}$ the isoprene emission rate was constantly increasing with higher light levels for the diatom Chaetoceros calcitrans, whereas the diatom Phaeodactylum tricornutum was highest at $200 \mu \mathrm{mol} \mathrm{m}{ }^{-2} \mathrm{~s}^{-1}$ and decreased at higher light levels. Furthermore, health conditions (Shaw et al., 2003), as well as the growth stage of the phytoplankton species (Milne et al., 1995), can also influence the isoprene emission rate.

With the new $P_{\text {calc }}$ values, we slightly overestimate the needed production $P_{\text {need }}$ by up to $20 \%$ on average (Fig. 5b, right part). For SPACES and OASIS, except for stations 1 and 10, using one $P_{\text {chloronew }}$ value for each PFT for the whole cruise is reasonable because the biogeochemistry in these regions did not differ much within one cruise. This was not true for ASTRA-OMZ, due to the biogeochemically contrasting open-ocean region and the coastal upwelling region. Using just one $P_{\text {chloronew value for each PFT for the whole cruise }}$ resulted in a highly overestimated and variable $P_{\text {calc }}$ value 

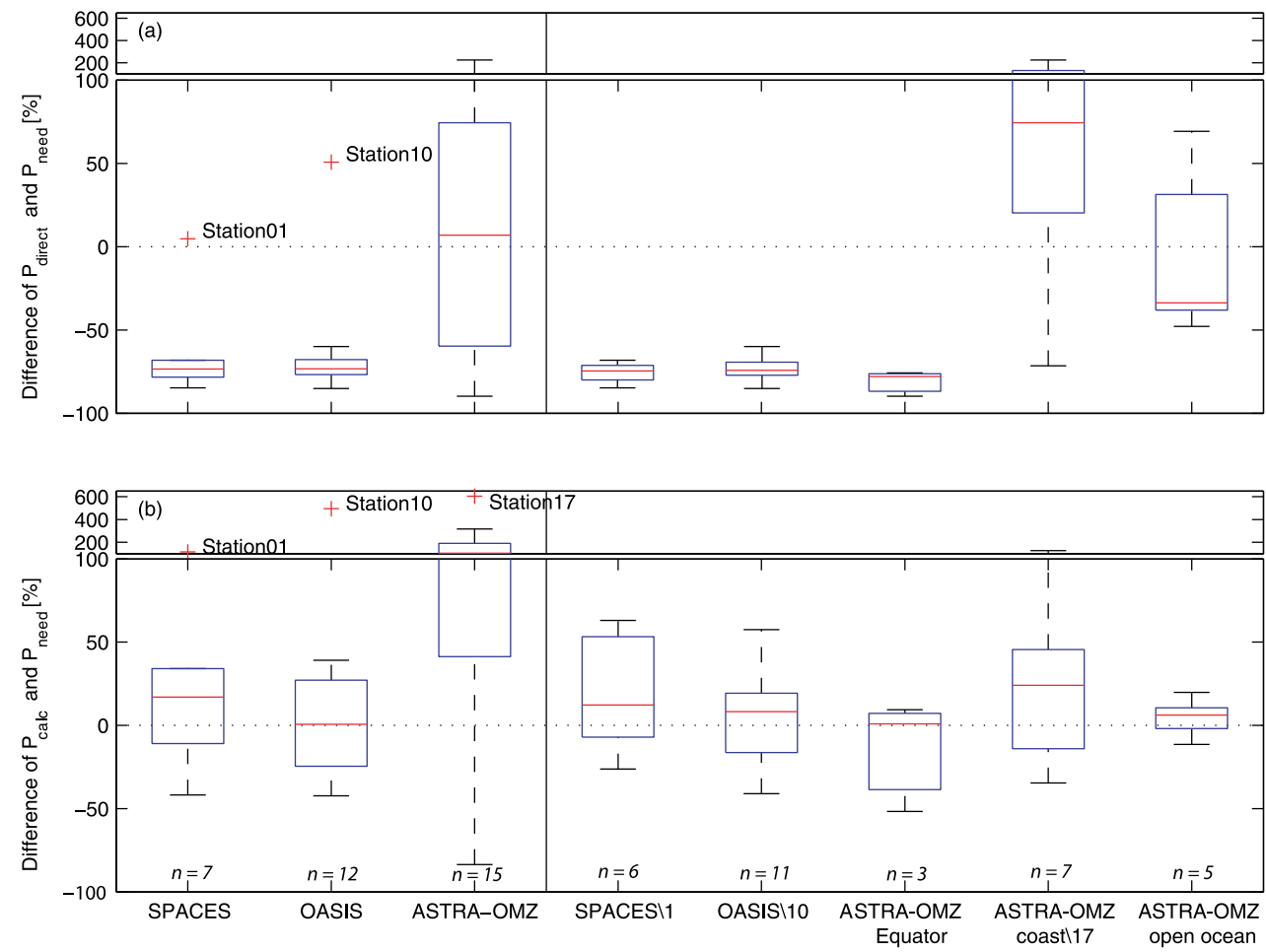

Figure 5. Percent differences between (a) $P_{\text {direct }}$ and $P_{\text {need }}\left(\left(P_{\text {direct }}-P_{\text {need }}\right) / P_{\text {need }}\right)$ and (b) $P_{\text {calc }}$ and $P_{\text {need }}\left(\left(P_{\text {calc }}-P_{\text {need }}\right) / P_{\text {need }}\right)$ for the different cruises/cruise regions. Left of the vertical black line, data are divided into the three different cruises; right of the vertical black line, data are shown for the three cruises with outliers from the left part excluded. Additionally, ASTRA-OMZ was split into three regions (Equator, coast, open ocean). Number of stations (n) used for each set of data are shown in italics. The red line represents the median, the boxes show the first to third quartile, and the whiskers illustrate the highest and lowest values that are not outliers. The red plus signs represent outliers. The number indicated after $\backslash$ denotes a station that has been excluded from the analysis.

Table 3. Calculated chl- $a$-normalized isoprene production rates $\left(P_{\text {chloronew }}, \mu \mathrm{mol}(\mathrm{g} \mathrm{chl} a)^{-1}\right.$ day $\left.^{-1}\right)$ of the three most abundant PFTs during SPACES and OASIS (haptophytes, cyanobacteria, Prochlorococcus) and ASTRA-OMZ (haptophytes, chlorophytes, diatoms). Number indicated after $\backslash$ denotes a station that has been excluded from the analysis. For explanation of the omission, please refer to Sect. 3.3.

\begin{tabular}{|c|c|c|c|c|c|c|}
\hline \multicolumn{2}{|l|}{ Cruise } & Haptophytes & Cyanobacteria & Prochlorococcus & Chlorophytes & Diatoms \\
\hline \multicolumn{2}{|l|}{ SPACES $\backslash 1$} & 0.5 & 44.7 & 0.5 & - & - \\
\hline \multicolumn{2}{|l|}{ OASIS $\backslash 10$} & 21.2 & 13.9 & 0.5 & - & - \\
\hline \multirow[t]{3}{*}{ ASTRA-OMZ } & Equator & 47.9 & - & - & 0.5 & 0.5 \\
\hline & Coast $\backslash 17$ & 9.6 & - & - & 6.1 & 0.6 \\
\hline & Open ocean & 10.3 & - & - & 0.5 & 0.5 \\
\hline \multicolumn{2}{|c|}{ Collection of literature values in Booge et al. (2016) } & 6.92 & 6.04 & $1.5^{\mathrm{a}}$ & 1.47 & $2.51^{\mathrm{a}}$ \\
\hline
\end{tabular}

${ }^{\text {a }}$ Production rates from Arnold et al. (2009) were excluded from literature values listed in Booge et al. (2016).

(Fig. 5b, "ASTRA-OMZ"). Therefore splitting this cruise into three different parts (Equator, coast, open ocean), due to their different chl $a$ concentration and nutrient availability, resulted in less variable $P_{\text {calc }}$ values. However, in the coastal region, the variability is still the highest, but with the newly derived $P_{\text {calc }}$ the agreement with $P_{\text {need }}$ is significantly better than with $P_{\text {direct }}$ (compare Fig. 5a and b).

\subsection{Drivers of isoprene production}

As mentioned above, no significant correlations between each calculated $P_{\text {chloronew }}$ value and any other parameter during the three cruises were found. Prochlorococcus was one of the three most abundant PFTs during SPACES and OASIS, but concentrations decrease to almost zero in the colder open-ocean and upwelling regions of ASTRA-OMZ (Fig. 1), which confirms the general knowledge that Prochlorococcus 

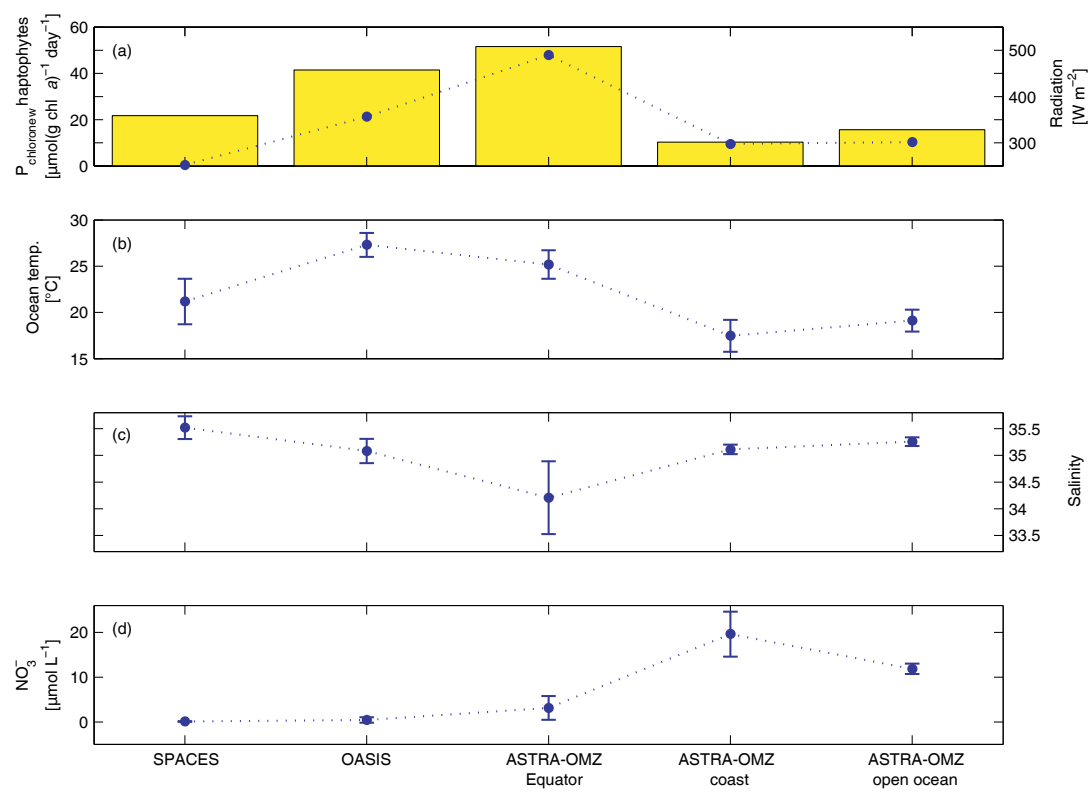

Figure 6. Mean values $( \pm \mathrm{SD})$ for (a) calculated $P_{\text {chloronew }}$ haptophytes (blue line) and global radiation (yellow bars), (b) ocean temperature, (c) salinity, and (d) nitrate during SPACES, OASIS, and ASTRA-OMZ (split into three different parts: Equator, coast, and open ocean).

is absent at temperatures $<15^{\circ} \mathrm{C}$ (Johnson et al., 2006). Our newly derived production rates confirm the actual laboratoryderived rates, demonstrating Prochlorococcus as a minor contributor to isoprene concentration. However, Prochlorococcus is especially abundant at high ocean temperatures, where isoprene production rates from the other PFTs show evidence of decreasing. Cyanobacteria concentrations (excluding Prochlorococcus) were also related to temperature, but, in contrast to Prochlorococcus, other cyanobacteria taxa can be abundant in colder waters during ASTRA-OMZ. The different derived isoprene production rates for SPACES and OASIS might be related to the different mean ocean temperature and light levels during these cruises. During SPACES, with lower ocean temperatures and lower light levels than OASIS, the production rate is higher. This relationship would confirm the findings of two independent laboratory studies of Bonsang et al. (2010) and Shaw et al. (2003). Bonsang et al. (2010) tested two species of cyanobacteria at $20^{\circ} \mathrm{C}$ and found higher isoprene production rates than a different species tested by Shaw et al. (2003) at $23^{\circ} \mathrm{C}$ and even stronger light intensities. However, Exton et al. (2013) measured the same rate as Shaw et al. (2003) at $26^{\circ} \mathrm{C}$ for one species, but a 5-times-higher production rate for another species at the same temperature. Because we do not know which species were present, we hypothesize that the production rate is not dependent on one environmental parameter and varies from species to species within the group of cyanobacteria.

Comparing the calculated isoprene production rates of the haptophytes with global radiation, ocean temperature, salinity, and nitrate results in some interesting qual- itative trends (Fig. 6). Mean global radiation during SPACES $\left(\sim 360 \mathrm{~W} \mathrm{~m}^{-2}\right)$ was lower than during OASIS $\left(\sim 457 \mathrm{~W} \mathrm{~m}^{-2}\right)$. Highest mean values were measured during ASTRA-OMZ (at the Equator, $\sim 508 \mathrm{~W} \mathrm{~m}^{-2}$ ). The same trend can be seen in the $P_{\text {chloronew }}$ values of the haptophytes. Within the open-ocean and coastal regimes of ASTRA$\mathrm{OMZ}$, the isoprene production rate was lower than around the Equator (mean global radiation decreased to $\sim 310 \mathrm{~W} \mathrm{~m}^{-2}$ ). A similar trend can be seen with the mean ocean temper-

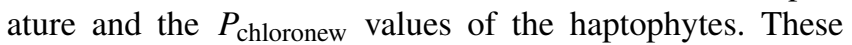
results are similar to several laboratory experiments with monocultures: higher light intensities and water temperatures enhance phytoplankton ability to produce isoprene (Shaw et al., 2003; Exton et al., 2013; Meskhidze et al., 2015). However, Meskhidze et al. (2015) showed in laboratory experiments that isoprene production rates from two diatoms species were highest when incubated in water temperatures of 22 to $26^{\circ} \mathrm{C}$. Higher temperatures caused a decrease in isoprene production rate. During OASIS, mean water temperatures were $27.3^{\circ} \mathrm{C}$ and went up to $29.2{ }^{\circ} \mathrm{C}$ near the Maldives. Increasing ocean temperatures influence the growth rate of phytoplankton generally, as well as differently within one group of PFTs. For haptophytes, Huertas et al. (2011) show that two strains of Emiliania huxleyi were not tolerant to a temperature increase from 22 to $30^{\circ} \mathrm{C}$, whereas Isochrysis galbana could adapt to the increased temperature. In general, the optimal growth rate temperature decreases with higher latitude (Chen, 2015), but the link between growth rate of phytoplankton and isoprene production rate is still not known. Assuming this temperature dependence can be transferred from diatoms also to haptophytes, the high sea- 
water temperatures during OASIS could explain why the calculated isoprene production rate is lower than in the ASTRA$\mathrm{OMZ}$ equatorial regime. Additionally, as mentioned before, the temperature as well as the light dependence of isoprene production might vary between different species of haptophytes when comparing different ocean regimes. Another reason for the very high isoprene production rate of haptophytes in the equatorial regime during ASTRA-OMZ, apart from temperature and light intensity, could be stress-induced production caused by low-salinity waters, which was already shown for dimethylsulfoniopropionate, a precursor for the climate-relevant trace gas dimethyl sulfide (DMS), produced by phytoplankton (Shenoy et al., 2000). The salinity is considerably lower at the Equator during ASTRA-OMZ than for all other cruise regions, with values down to 33.4. We observed that the $P_{\text {chloronew }}$ values decrease again in regions with more saline waters, where phytoplankton likely experiences less stress due to salinity, temperature, or light levels (Fig. 6).

In order to identify parameters that influence not only the chl- $a$-normalized isoprene production rate of haptophytes but the rate of all PFTs together, we calculated a normalized isoprene production rate $\left(P_{\text {norm }}\right)$ independent from the absolute amount of each PFT. Hence, we divided each $P_{\text {calc }}$ value at every station by the amount of the three most abundant PFTs:

$$
P_{\text {norm }}=\frac{\sum_{i=1}^{3} P_{\text {chloronew }_{i}} \times[\mathrm{PFT}]_{i}}{\sum_{i=1}^{3}[\mathrm{PFT}]_{i}}=\frac{P_{\text {calc }}}{\sum_{i=1}^{3}[\mathrm{PFT}]_{i}},
$$

where $i$ is three most abundant PFTs during each cruise.

The $P_{\text {norm }}$ value helps us to obtain more insight about the influencing factors at each station, rather than only one mean data point for each cruise. We plotted the $P_{\text {norm }}$ values of each station vs. the ocean temperature and colorcoded them by nitrate concentration as a marker for the nutrient availability (Fig. 7). During SPACES (squares) and OASIS (triangles), the normalized production rate is on average $12.8 \pm 2.2$ pmol $(\mu \mathrm{g} \text { PFT })^{-1} \mathrm{day}^{-1}$ and independent from the ocean temperature, while the nitrate concentration is very low $\left(0.33 \pm 0.53 \mu \mathrm{molL}^{-1}\right)$. During ASTRA-OMZ (circles) in the coastal and open-ocean regions, the nitrate concentrations were significantly higher $\left(16.4 \pm 5.5 \mu \mathrm{molL}^{-1}\right)$, but the $P_{\text {norm }}$ values were lower $\left(<8 \mathrm{pmol}(\mu \mathrm{g} \mathrm{PFT})^{-1}\right.$ day $\left.^{-1}\right)$, correlating with lower ocean temperatures. In the equatorial region of ASTRA-OMZ, the production rates are significantly higher than during SPACES and OASIS, at up to $36.4 \mathrm{pmol}(\mu \mathrm{g} \text { PFT })^{-1} \mathrm{day}^{-1}$. On the right panel of Fig. 7, the mean salinity for each $P_{\text {norm-dependent box (separated }}$ by the dashed lines) is shown. ASTRA-OMZ (Equator) and SPACES and OASIS do not differ in ocean temperature or in nitrate concentration. However, the normalized production is significantly higher at the ASTRA-OMZ equatorial region, which may be caused by the low salinity there. In summary, (1) during ASTRA-OMZ (coast, open ocean) $P_{\text {norm }}$ is comparatively lower $\left(<8\right.$ pmol $(\mu \mathrm{g} \text { PFT })^{-1}$ day $\left.^{-1}\right)$ under "biogeochemically active" conditions (high nitrate concentration) but increases with increasing ocean temperature; (2) under limited-nutrient conditions $P_{\text {norm }}$ is significantly increased likely due to nutrient stress; and (3) if the phytoplankton are additionally stressed due to lower salinity, $P_{\text {norm }}$ is furthermore increased. These results show that there is no main parameter driving the isoprene production rate, resulting in a more complex interaction of physical and biological parameters influencing the phytoplankton to produce isoprene.

\subsection{Loss processes}

The comparison between $P_{\text {calc }}$ and $P_{\text {need }}$ in Fig. 5b shows a mean overestimation of $10-20 \%$. This is likely due to a missing loss term in the calculation, which would balance out the needed and calculated isoprene production. Chemical loss (red dashed line) and loss due to air-sea gas exchange (black solid line) using the gas transfer parameterization of Wanninkhof (1992) were already included in the calculation (Eq. 10), and their loss rate constants are shown in Fig. 8. For comparison, we added the $k_{\mathrm{AS}}$ values using the parameterizations of Wanninkhof and McGillis (1999) (black dotted line) and Nightingale et al. (2000) (black dashed line). They have different wind speed dependencies of gas transfer, which could influence the computed isoprene loss at high wind speeds. The parameterization of Wanninkhof and McGillis (1999) is cubic and will increase the loss rate constant of isoprene due to air-sea gas exchange at high wind speeds compared to the other parameterizations (Fig. 8, OASIS). Nightingale et al. (2000) is a combined linear and quadratic parameterization, which would decrease the isoprene loss due to air-sea gas exchange. However, during SPACES and ASTRA-OMZ the wind speed was between 8 and $10 \mathrm{~m} \mathrm{~s}^{-1}$, where the parameterization of Wanninkhof (1992) is higher than both Wanninkhof and McGillis (1999) and Nightingale et al. (2000). Therefore the use of these alternative parameterizations would even lower the loss rate constant due to air-sea gas exchange, leading to the need for an additional loss rate in order to balance the isoprene production.

To calculate the additionally required consumption rate $\left(k_{\text {consumption }}\right)$, we only used stations where a loss term was actually needed to balance the calculated and needed production $\left(P_{\text {calc }}>P_{\text {need }}\right)$. Those values were averaged within each cruise and are shown in Fig. 8. For comparison, we added the loss rate constants due to bacterial consumption from Palmer and Shaw (2005) (blue dashed line; 0.06 day $^{-1}$ ) and an updated value from Booge et al. (2016) (blue dotted line; $\left.0.01 \mathrm{day}^{-1}\right)$. Comparable to the chemical loss rate, the $k_{\mathrm{BIOL}}$ values were assumed to be constant (following the assumption of Palmer and Shaw, 2005), because no data about bacterial isoprene consumption in surface waters are avail- 
$\mathrm{NO}_{3}{ }^{-}\left[\mu \mathrm{mol} \mathrm{L}{ }^{-1}\right]$
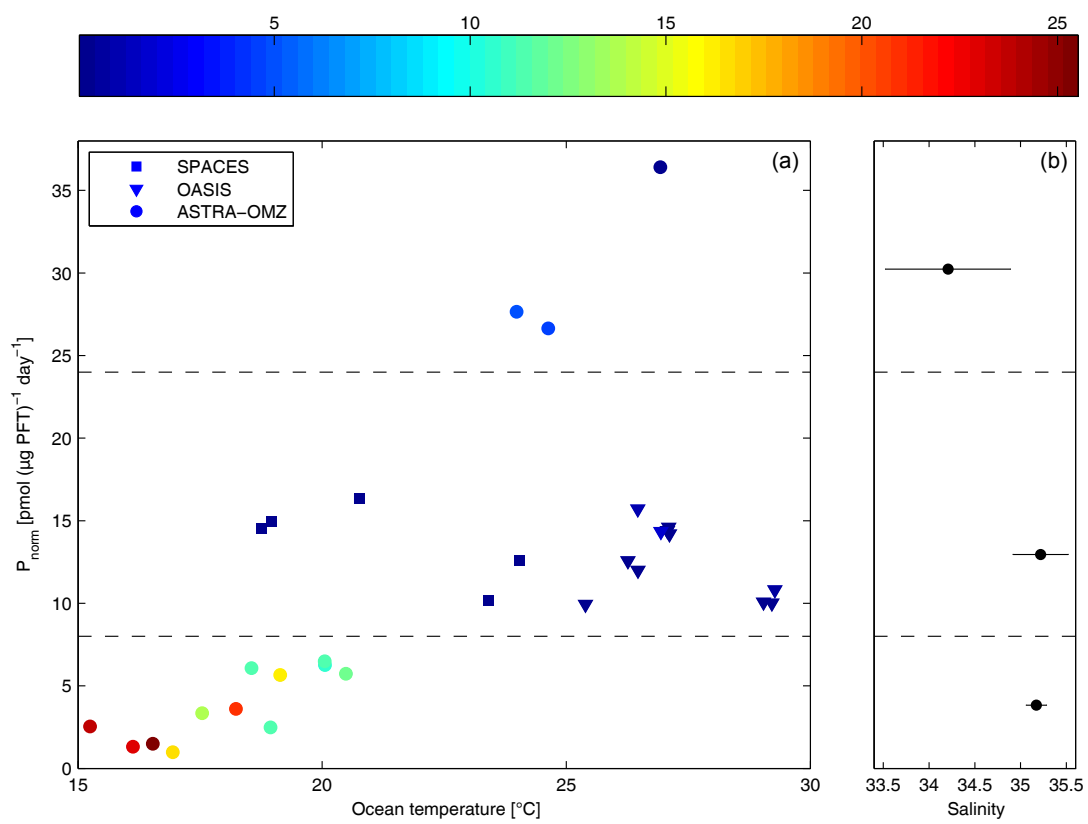

Figure 7. Left panel: relationship between $P_{\text {norm }}$ in $\mathrm{pmol}\left(\mu \mathrm{g}\right.$ PFT) ${ }^{-1}$ day ${ }^{-1}$ and ocean temperature in ${ }^{\circ} \mathrm{C}$ during SPACES (squares), OASIS (triangles), and ASTRA-OMZ (circles) color-coded by $\mathrm{NO}_{3}^{-}$in $\mu \mathrm{molL}^{-1}$. Right panel: mean salinity $( \pm \mathrm{SD})$ of samples from left side plot in each box divided by dashed lines.

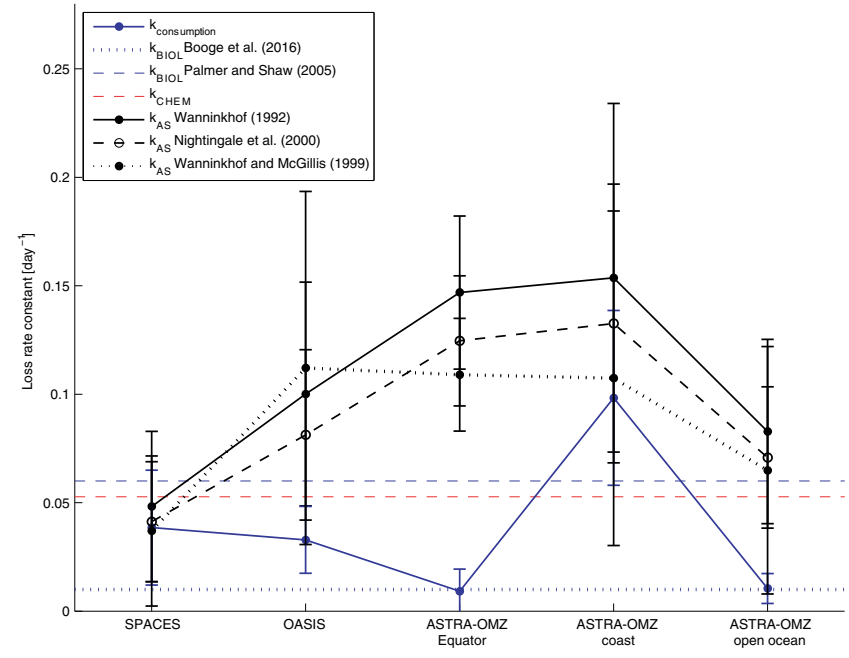

Figure 8. Different mean loss rate constants $( \pm S D)$ during SPACES, OASIS; and ASTRA-OMZ. Blue points: calculated loss rate $\left(k_{\text {consumption }}\right)$; blue dotted line: $k_{\mathrm{BIOL}}$ from Booge et al. (2016); blue dashed line: $k_{\mathrm{BIOL}}$ from Palmer and Shaw (2005); red dashed line: $k_{\mathrm{CHEM}}$; black points: calculated loss rate constants due to air-sea gas exchange.

able. Figure 8 clearly shows that the needed loss rate constant is not a constant factor. During SPACES and OASIS the loss rate constant is roughly in the middle of the assumed $k_{\mathrm{BIOL}}$ values of Palmer and Shaw (2005) and Booge

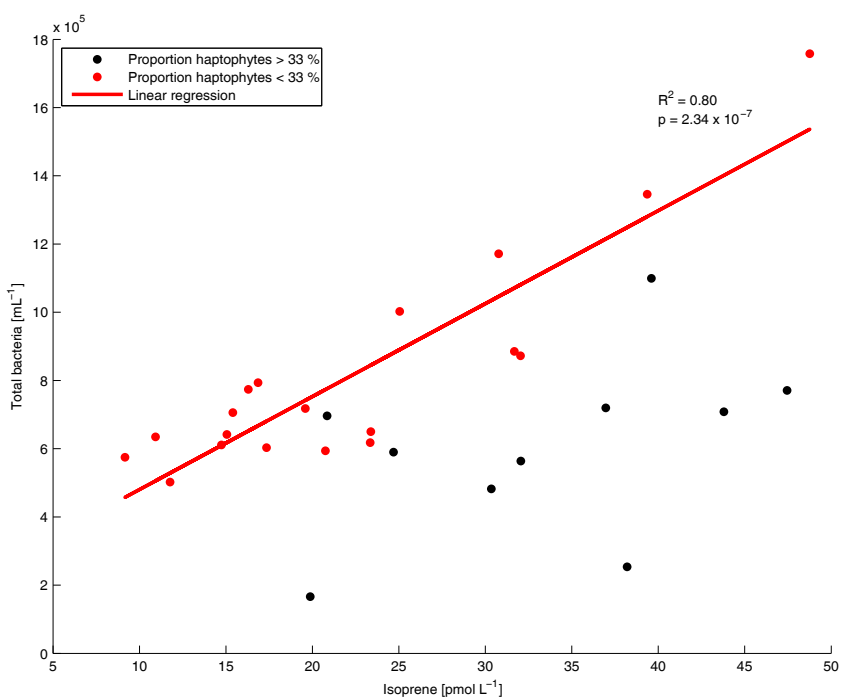

Figure 9. Relationship between isoprene concentration $\left(\mathrm{pmol} \mathrm{L}^{-1}\right)$ and total bacteria counts $\left.\left(\mathrm{mL}^{-1}\right]\right)$ during SPACES, OASIS, and ASTRA-OMZ. Black and red points represent samples where the contribution of haptophytes to the total phytoplankton chl $a$ concentration is higher and lower than $33 \%$, respectively. Linear regression $\left(R^{2}=0.80 ; p=2.34 \times 10^{-7}\right)$ for red points only.

et al. (2016), whereas during ASTRA-OMZ (Equator and open ocean) the calculated loss rate constant fits quite well with the assumed value of Booge et al. (2016). In all four re- 

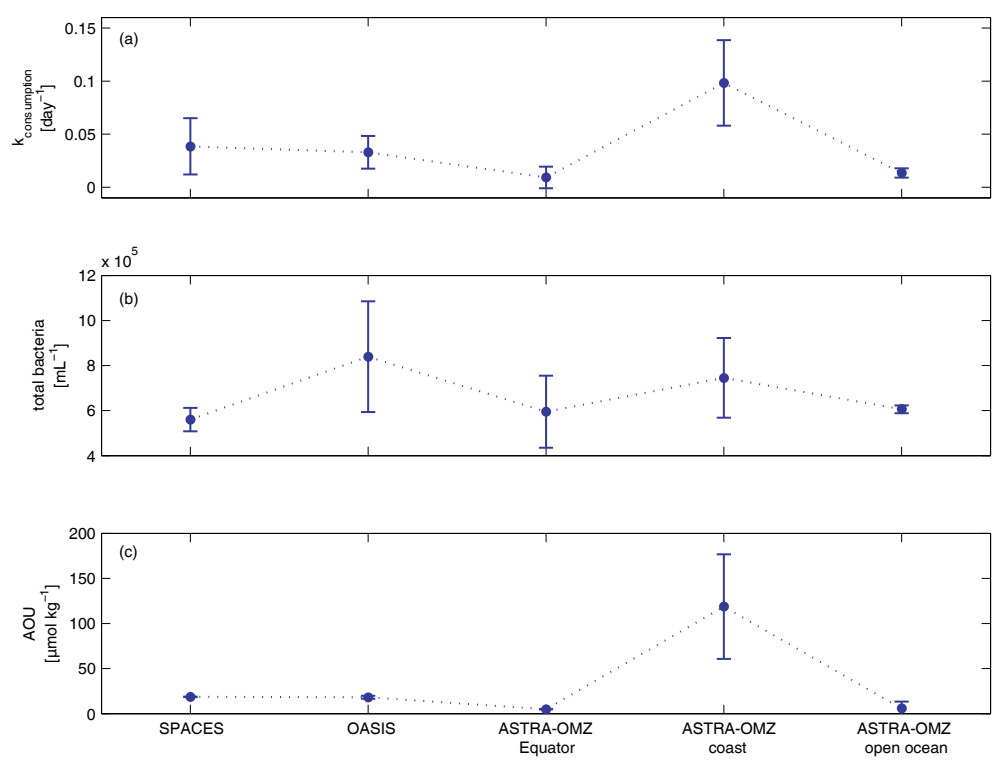

Figure 10. Mean values $( \pm \mathrm{SD})$ for (a) $k_{\text {consumption }}\left(\right.$ day $\left.^{-1}\right)$, (b) total bacteria counts $\left(\mathrm{mL}^{-1}\right)$, and (c) AOU $\left(\mu \mathrm{molL} \mathrm{L}^{-1}\right)$ during SPACES, OASIS, and ASTRA-OMZ (split into three different parts: Equator, coast, and open ocean).

gions, the additional calculated sink is lower than the chemical loss and the loss due to air-sea gas exchange, which is not true for the coastal region of ASTRA-OMZ. Here, the loss rate constant $\left(0.1 \mathrm{day}^{-1}\right)$ is about 10 times higher than in the open-ocean region, resulting in a lifetime of isoprene of only 10 days, which is comparable to the lifetime due to air-sea gas exchange during ASTRA-OMZ (open ocean) and OASIS. Physical loss, like advective mixing through the thermocline, cannot account for this sink, as this lifetime is assumed to be several years (Palmer and Shaw, 2005) and, therefore, negligible. Even a change in the chemical loss rate would only change the absolute value of the calculated loss rate constant, but not its variability. We tested a temperaturedependent rate for the reaction with $\mathrm{OH}$, but the mean difference of the temperature-dependent $k_{\text {CHEM }}$ to the nontemperature-dependent $k_{\text {CHEM }}$ was less than $2 \%$ for all temperature regimes during the cruises and, therefore, negligible. It must be noted that the loss rate due to the reaction with $\mathrm{OH}$ is a gas phase reaction rate (Atkinson et al., 2004), and the rate used for reaction with singlet oxygen derives from measurements in chloroform (Monroe, 1981), meaning that these rates might not be suitable for isoprene reactions in the water phase. These rates, involving possible temperature and pressure dependencies, have to be evaluated in seawater in order to determine the chemical loss in the water column.

Marine-produced halocarbons, like dibromomethane and methyl bromide, are known to undergo bacterial degradation (Goodwin et al., 1998). Compared to halocarbons, isoprene is not toxic and has two energy-rich double bonds and, therefore, may even be favored to be oxidized by heterotrophic marine bacteria (Acuñ a Alvarez et al., 2009). Figure 9 shows a comparison of total bacteria counts and isoprene concentra- tion from each station in the MLD. The correlation between bacteria and the concentration of isoprene is only significant when haptophytes are less than $33 \%$ of the total phytoplankton chl $a$ concentration $\left(R^{2}=0.80 ; p=2.34 \times 10^{-7}\right)$. Haptophytes were one of the three dominant PFTs during all cruises and had a mean calculated isoprene production rate of $17.9 \mu \mathrm{mol}(\mathrm{g} \mathrm{chl} a)^{-1} \mathrm{day}^{-1}$ (Table 3). This is a high isoprene production rate, and we could assume higher isoprene concentrations with higher concentrations of haptophytes. This relationship, however, is not evident (data not shown), which may indicate that other processes mask this relationship Multiplying the chl- $a$-normalized isoprene production rate of $17.9 \mu \mathrm{mol}(\mathrm{g} \mathrm{chl} a)^{-1}$ day $^{-1}$ with the chl $a$ concentration of haptophytes results in a mean isoprene production rate of $\sim 3 \mathrm{pmolL}^{-1} \mathrm{day}^{-1}$, which is about 4 times higher than the mean calculated loss rate due to bacterial degradation over all cruises $\left(\sim 0.8 \mathrm{pmolL}^{-1} \mathrm{day}^{-1}\right)$. This could hide the correlation of isoprene concentrations with bacteria when haptophytes are dominant (>33\%). In addition, haptophytes themselves are suggested to be the main marine bacterial grazers, compared to other PFTs (Unrein et al., 2014). This leads to the hypothesis that, if there is a lot of isoprene abundant which can be used (e.g., as an energy source) by bacteria, the bacteria abundance will also increase, independent of any PFT. However, if the phytoplankton community is dominated $(>33 \%)$ by haptophytes, the isoprene concentration is no longer correlated with the bacteria abundance, due to the grazing of bacteria by haptophytes (Fig. 9, total bacteria cell counts of black points are lower than those of the red points at similar isoprene concentrations).

Due to the different loss rate constants of bacterial degradation $\left(\sim 0.01\right.$ day $^{-1}$ during ASTRA-OMZ (Equator) com- 
pared to $\sim 0.1 \mathrm{day}^{-1}$ in the coastal region of ASTRA-OMZ, Fig. 8) in the different regions, it is important to identify their dependence on environmental parameters. Unfortunately, the absolute amount of bacteria does not have a significant influence on $k_{\text {consumption }}$ (Fig. 10a and b), which may be caused by different heterotrophic bacteria, each with a different ability to use isoprene as an energy source. However, we find a similar qualitative trend for $k_{\text {consumption }}$ and the apparent oxygen utilization (AOU) (difference between the equilibrium oxygen saturation concentration and the actual measured dissolved oxygen concentration) during the three cruises (Fig. 10c). The higher loss rate constant of isoprene due to possible bacterial consumption coincides with considerably higher AOU values in the coastal regime of ASTRAOMZ, which may be caused by heterotrophic respiration. Even if this correlation is not significant, this trend points to the influence of environmental conditions on biological activity, which in turn influences the isoprene consumption.

\section{Conclusions}

For the first time, marine isoprene measurements were performed in the eastern Pacific Ocean. In addition, our isoprene measurements in the highly undersampled Indian Ocean further increase the small dataset of oceanic isoprene measurements in this region. The results from both oceans show that isoprene is well mixed in the MLD. Despite the known biogenic origin of isoprene, the marine isoprene concentrations cannot be described globally with a simple parameterization including chl $a$ concentration or SST or a combination of both. On regional scales this relationship might sometimes be significant (Ooki et al., 2015; Hackenberg et al., 2017), but laboratory monoculture experiments show that isoprene production rates range widely over all different PFTs, as well as within one PFT (collection of literature values in Booge et al., 2016). The production rates from laboratory experiments have to be evaluated in the field, as different PFTs are not distributed equally over the world ocean and are also influenced by temperature and salinity, as well as changing light levels. Therefore we used isoprene measurements as well as different phytoplankton marker pigment measurements to derive in-field production rates for haptophytes, cyanobacteria, Prochlorococcus, chlorophytes, and diatoms in different regions. The results confirm findings from previous laboratory studies that the isoprene production is influenced by light and ocean temperature, due to stress, and by nutrients, due to their effect on changing phytoplankton communities and their abundances (e.g., Dani and Loreto, 2017; Shaw et al., 2010). Moreover, our data lead to the conclusion that isoprene production rates in the field, irrespective of phytoplankton communities and their abundance, are influenced by nutrient levels, which has never been shown before. Additionally, we show that isoprene production rates are influenced by salinity levels, which has also been shown in previ- ous studies (Rinnan et al., 2014, and references therein). Our calculations also show that, besides chemical loss and the loss due to air-sea gas exchange, another non-static isoprene consumption process has to be taken into account to understand isoprene concentrations in the surface ocean. This loss may be attributed to bacterial degradation or, more generally, to heterotrophic respiration, as we could show a similar qualitative trend between the additional loss rate constant and the AOU. These results clearly indicate that further experiments are needed to evaluate isoprene production rates for every PFT in general, as well as under different biogeochemical conditions (light, salinity, temperature, nutrients). With the help of incubation experiments under different conditions, the additional loss process can be investigated. Exact knowledge of the different production and loss processes, as well as their interaction, is crucial in understanding global marine isoprene cycling. Furthermore, the most appropriate wind-speed-based $k$ parameterization to compute air-sea gas exchange, the main loss process for isoprene in the ocean, must be used in future studies. Different parameterizations under different wind levels highly influence the loss term, which is additionally influenced by surface films at low wind speeds or bubble generation at high wind speeds. Isoprene loss processes, in conjunction with the complexity of isoprene production, should be further examined in order to predict marine isoprene concentrations and evaluate the impact of isoprene on SOA formation over the remote open ocean.

Data availability. All isoprene data and bacterial cell counts are available from the corresponding author. Pigment and nutrient data from SPACES and OASIS and from ASTRA-OMZ will be available from PANGAEA but for now can be obtained through the corresponding author.

\section{The Supplement related to this article is available online at https://doi.org/10.5194/bg-15-649-2018-supplement.}

Competing interests. The authors declare that they have no conflict of interest.

Acknowledgements. The authors would like to thank the captain and crew of the R/V Sonne during SPACES and OASIS and during ASTRA-OMZ, as well as the chief scientist Kirstin Krüger (SPACES and OASIS) and the co-chief Damian Grundle (ASTRAOMZ). We thank Sonja Wiegmann for HPLC pigment analysis of SPACES, OASIS, and ASTRA-OMZ samples; Sonja Wiegmann and Wee Cheah for pigment sampling during SPACES and OASIS; Rüdiger Röttgers for helping with pigment sampling and radiation measurements during ASTRA-OMZ; Tania Klüver for flow cytometry analysis; and Martina Lohmann for nutrient sampling and analysis during SPACES, OASIS, and ASTRA-OMZ. The authors 
gratefully acknowledge NASA for providing the MODIS-Aqua satellit data. Sonja Endres' work was additionally funded by the Cluster of Excellence 80 "The Future Ocean". The Future Ocean is funded within the framework of the Excellence Initiative by the Deutsche Forschungsgemeinschaft (DFG) on behalf of the German federal and state governments. This work was carried out under the Helmholtz Young Investigator Group of Christa A. Marandino, TRASE-EC (VH-NG-819), from the Helmholtz Association through the President's Initiative and Networking Fund and the GEOMAR Helmholtz-Zentrum für Ozeanforschung Kiel. The $\mathrm{R} / \mathrm{V}$ Sonne I cruises SPACES and OASIS and the R/V Sonne II cruise ASTRA-OMZ were financed by the BMBF through grants 03G0235A and 03G0243A, respectively.

The article processing charges for this open-access

publication were covered by a Research

Centre of the Helmholtz Association.

Edited by: Gerhard Herndl

Reviewed by: two anonymous referees

\section{References}

Acuña Alvarez, L., Exton, D. A., Timmis, K. N., Suggett, D. J., and McGenity, T. J.: Characterization of marine isoprenedegrading communities, Environ. Microbiol., 11, 3280-3291, https://doi.org/10.1111/j.1462-2920.2009.02069.x, 2009.

Aiken, J., Pradhan, Y., Barlow, R., Lavender, S., Poulton, A., Holligan, P., and Hardman-Mountford, N.: Phytoplankton pigments and functional types in the Atlantic Ocean: a decadal assessment, 1995-2005, Deep-Sea Res. Pt. II, 56, 899-917, https://doi.org/10.1016/j.dsr2.2008.09.017, 2009.

Anttila, T., Langmann, B., Varghese, S., and O'Dowd, C.: Contribution of isoprene oxidation products to marine aerosol over the North-East Atlantic, Adv. Meteorol., 482603, https://doi.org/10.1155/2010/482603, 2010.

Arneth, A., Monson, R. K., Schurgers, G., Niinemets, Ü., and Palmer, P. I.: Why are estimates of global terrestrial isoprene emissions so similar (and why is this not so for monoterpenes)?, Atmos. Chem. Phys., 8, 4605-4620, https://doi.org/10.5194/acp8-4605-2008, 2008.

Arnold, S. R., Spracklen, D. V., Williams, J., Yassaa, N., Sciare, J., Bonsang, B., Gros, V., Peeken, I., Lewis, A. C., Alvain, S., and Moulin, C.: Evaluation of the global oceanic isoprene source and its impacts on marine organic carbon aerosol, Atmos. Chem. Phys., 9, 1253-1262, https://doi.org/10.5194/acp-9-1253-2009, 2009.

Atkinson, R. and Arey, J.: Atmospheric degradation of volatile organic compounds, Chem. Rev., 103, 4605-4638, 2003.

Atkinson, R., Baulch, D. L., Cox, R. A., Crowley, J. N., Hampson, R. F., Hynes, R. G., Jenkin, M. E., Rossi, M. J., and Troe, J.: Evaluated kinetic and photochemical data for atmospheric chemistry: Volume $\mathrm{I}-$ gas phase reactions of $\mathrm{O}_{x}, \mathrm{HO}_{x}$, $\mathrm{NO}_{x}$ and $\mathrm{SO}_{x}$ species, Atmos. Chem. Phys., 4, 1461-1738, https://doi.org/10.5194/acp-4-1461-2004, 2004.

Baker, A. R., Turner, S. M., Broadgate, W. J., Thompson, A., McFiggans, G. B., Vesperini, O., Nightingale, P. D., Liss, P. S., and Jickells, T. D.: Distribution and sea-air fluxes of biogenic trace gases in the eastern Atlantic Ocean, Global Biogeochem. Cy., 14, 871-886, https://doi.org/10.1029/1999gb001219, 2000.

Barlow, R. G., Cummings, D. G., and Gibb, S. W.: Improved resolution of mono- and divinyl chlorophylls $\mathrm{a}$ and $\mathrm{b}$ and zeaxanthin and lutein in phytoplankton extracts using reverse phase C-8 HPLC, Mar. Ecol.-Prog. Ser., 161, 303-307, https://doi.org/10.3354/meps161303, 1997.

Bonsang, B., Polle, C., and Lambert, G.: Evidence for marine production of isoprene, Geophys. Res. Lett., 19, 1129-1132, https://doi.org/10.1029/92gl00083, 1992.

Bonsang, B., Gros, V., Peeken, I., Yassaa, N., Bluhm, K., Zoellner, E., Sarda-Esteve, R., and Williams, J.: Isoprene emission from phytoplankton monocultures: the relationship with chlorophyll $a$, cell volume and carbon content, Environ. Chem., 7, 554563, https://doi.org/10.1071/En09156, 2010.

Booge, D., Marandino, C. A., Schlundt, C., Palmer, P. I., Schlundt, M., Atlas, E. L., Bracher, A., Saltzman, E. S., and Wallace, D. W. R.: Can simple models predict large-scale surface ocean isoprene concentrations?, Atmos. Chem. Phys., 16, 11807-11821, https://doi.org/10.5194/acp-16-11807-2016, 2016.

Broadgate, W. J., Liss, P. S., and Penkett, S. A.: Seasonal emissions of isoprene and other reactive hydrocarbon gases from the ocean, Geophys. Res. Lett., 24, 2675-2678, https://doi.org/10.1029/97g102736, 1997.

Broadgate, W. J., Malin, G., Kupper, F. C., Thompson, A., and Liss, P. S.: Isoprene and other non-methane hydrocarbons from seaweeds: a source of reactive hydrocarbons to the atmosphere, Mar. Chem., 88, 61-73, https://doi.org/10.1016/j.marchem.2004.03.002, 2004

Carlton, A. G., Wiedinmyer, C., and Kroll, J. H.: A review of Secondary Organic Aerosol (SOA) formation from isoprene, Atmos. Chem. Phys., 9, 4987-5005, https://doi.org/10.5194/acp-9-49872009, 2009.

Chavez, F. P. and Messié, M.: A comparison of eastern boundary upwelling ecosystems, Prog. Oceanogr., 83, 80-96, https://doi.org/10.1016/j.pocean.2009.07.032, 2009.

Chen, B.: Patterns of thermal limits of phytoplankton, J. Plankton Res., 37, 285-292, https://doi.org/10.1093/plankt/fbv009, 2015.

Dani, K. G. S. and Loreto, F.: Trade-off between dimethyl sulfide and isoprene emissions from marine phytoplankton, Trends Plant Sci., 22, 361-372, https://doi.org/10.1016/j.tplants.2017.01.006, 2017.

de Boyer Montégut, C., Madec, G., Fischer, A. S., Lazar, A., and Iudicone, D.: Mixed layer depth over the global ocean: an examination of profile data and a profilebased climatology, J. Geophys. Res.-Oceans, 109, C12003, https://doi.org/10.1029/2004JC002378, 2004.

Exton, D. A., Suggett, D. J., McGenity, T. J., and Steinke, M.: Chlorophyll-normalized isoprene production in laboratory cultures of marine microalgae and implications for global models, Limnol. Oceanogr., 58, 1301-1311, 2013.

Gantt, B., Meskhidze, N., and Kamykowski, D.: A new physicallybased quantification of marine isoprene and primary organic aerosol emissions, Atmos. Chem. Phys., 9, 4915-4927, https://doi.org/10.5194/acp-9-4915-2009, 2009.

Gasol, J. M. and Del Giorgio, P. A.: Using flow cytometry for counting natural planktonic bacteria and understanding the structure of planktonic bacterial communities, Sci. Mar., 64, 197-224, 2000. 
Goodwin, K. D., Schaefer, J. K., and Oremland, R. S.: Bacterial oxidation of dibromomethane and methyl bromide in natural waters and enrichment cultures, Appl. Environ. Microb., 64, 46294636, 1998.

Guenther, A., Karl, T., Harley, P., Wiedinmyer, C., Palmer, P. I., and Geron, C.: Estimates of global terrestrial isoprene emissions using MEGAN (Model of Emissions of Gases and Aerosols from Nature), Atmos. Chem. Phys., 6, 3181-3210, https://doi.org/10.5194/acp-6-3181-2006, 2006.

Guenther, A. B., Monson, R. K., and Fall, R.: Isoprene and monoterpene emission rate variability - observations with eucalyptus and emission rate algorithm development, J. Geophys. Res.-Atmos., 96, 10799-10808, https://doi.org/10.1029/91jd00960, 1991.

Guenther, A. B., Jiang, X., Heald, C. L., Sakulyanontvittaya, T., Duhl, T., Emmons, L. K., and Wang, X.: The Model of Emissions of Gases and Aerosols from Nature version 2.1 (MEGAN2.1): an extended and updated framework for modeling biogenic emissions, Geosci. Model Dev., 5, 1471-1492, https://doi.org/10.5194/gmd-5-1471-2012, 2012.

Hackenberg, S. C., Andrews, S. J., Airs, R., Arnold, S. R., Bouman, H. A., Brewin, R. J. W., Chance, R. J., Cummings, D., Dall'Olmo, G., Lewis, A. C., Minaeian, J. K., Reifel, K. M., Small, A., Tarran, G. A., Tilstone, G. H., and Carpenter, L. J.: Potential controls of isoprene in the surface ocean, Global Biogeochem. Cy., 31, 644-662, https://doi.org/10.1002/2016GB005531, 2017.

Heald, C. L., Henze, D. K., Horowitz, L. W., Feddema, J., Lamarque, J. F., Guenther, A., Hess, P. G., Vitt, F., Seinfeld, J. H., Goldstein, A. H., and Fung, I.: Predicted change in global secondary organic aerosol concentrations in response to future climate, emissions, and land use change, J. Geophys. Res.-Atmos., 113, 16, https://doi.org/10.1029/2007jd009092, 2008.

Henze, D. K. and Seinfeld, J. H.: Global secondary organic aerosol from isoprene oxidation, Geophys. Res. Lett., 33, L09812, https://doi.org/10.1029/2006gl025976, 2006.

Hoyle, C. R., Berntsen, T., Myhre, G., and Isaksen, I. S. A.: Secondary organic aerosol in the global aerosol - chemical transport model Oslo CTM2, Atmos. Chem. Phys., 7, 5675-5694, https://doi.org/10.5194/acp-7-5675-2007, 2007.

Hu, Q.-H., Xie, Z.-Q., Wang, X.-M., Kang, H., He, Q.-F., and Zhang, P.: Secondary organic aerosols over oceans via oxidation of isoprene and monoterpenes from Arctic to Antarctic, Sci. Rep.-UK, 3, 2280, https://doi.org/10.1038/srep02280, available at: http://www.nature.com/articles/srep02280\# supplementary-information, 2013.

Huertas, I. E., Rouco, M., López-Rodas, V., and Costas, E.: Warming will affect phytoplankton differently: evidence through a mechanistic approach, P. Roy. Soc. B Biol. Sci., 278, 35343543, https://doi.org/10.1098/rspb.2011.0160, 2011.

Jacovides, C. P., Timvios, F. S., Papaioannou, G., Asimakopoulos, D. N., and Theofilou, C. M.: Ratio of PAR to broadband solar radiation measured in Cyprus, Agr. Forest Meteorol., 121, 135140, https://doi.org/10.1016/j.agrformet.2003.10.001, 2004.

Johnson, Z. I., Zinser, E. R., Coe, A., McNulty, N. P., Woodward, E. M. S., and Chisholm, S. W.: Niche partitioning among Prochlorococcus ecotypes along oceanscale environmental gradients, Science, 311, 1737-1740, https://doi.org/10.1126/science.1118052, 2006.
Kameyama, S., Yoshida, S., Tanimoto, H., Inomata, S., Suzuki, K., and Yoshikawa-Inoue, H.: High-resolution observations of dissolved isoprene in surface seawater in the Southern Ocean during austral summer 2010-2011, J. Oceanogr., 70, 225-239, https://doi.org/10.1007/s10872-014-0226-8, 2014.

Kurihara, M., Iseda, M., Ioriya, T., Horimoto, N., Kanda, J., Ishimaru, T., Yamaguchi, Y., and Hashimoto, S.: Brominated methane compounds and isoprene in surface seawater of Sagami Bay: concentrations, fluxes, and relationships with phytoplankton assemblages, Mar. Chem., 134, 71-79, https://doi.org/10.1016/j.marchem.2012.04.001, 2012.

Kurihara, M. K., Kimura, M., Iwamoto, Y., Narita, Y., Ooki, A., Eum, Y. J., Tsuda, A., Suzuki, K., Tani, Y., Yokouchi, Y., Uematsu, M., and Hashimoto, S.: Distributions of short-lived iodocarbons and biogenic trace gases in the open ocean and atmosphere in the western North Pacific, Mar. Chem., 118, 156170, https://doi.org/10.1016/j.marchem.2009.12.001, 2010.

Lelieveld, J., Butler, T. M., Crowley, J. N., Dillon, T. J., Fischer, H., Ganzeveld, L., Harder, H., Lawrence, M. G., Martinez, M., Taraborrelli, D., and Williams, J.: Atmospheric oxidation capacity sustained by a tropical forest, Nature, 452, 737740, https://doi.org/10.1038/nature06870, 2008.

Matsunaga, S., Mochida, M., Saito, T., and Kawamura, K.: In situ measurement of isoprene in the marine air and surface seawater from the western North Pacific, Atmos. Environ., 36, 6051-6057, https://doi.org/10.1016/s1352-2310(02)00657-x, 2002.

Meskhidze, N., Sabolis, A., Reed, R., and Kamykowski, D.: Quantifying environmental stress-induced emissions of algal isoprene and monoterpenes using laboratory measurements, Biogeosciences, 12, 637-651, https://doi.org/10.5194/bg-12-6372015, 2015.

Milne, P. J., Riemer, D. D., Zika, R. G., and Brand, L. E.: Measurement of vertical-distribution of isoprene in surface seawater, its chemical fate, and its emission from several phytoplankton monocultures, Mar. Chem., 48, 237-244, https://doi.org/10.1016/0304-4203(94)00059-M, 1995.

Monroe, B. M.: Rate constants for the reaction of singlet oxygen with conjugated dienes, J. Am. Chem. Soc., 103, 7253-7256, https://doi.org/10.1021/ja00414a035, 1981.

Morel, A. and Berthon, J. F.: Surface pigments, algal biomass profiles, and potential production of the euphotic layer - relationships reinvestigated in view of remote-sensing applications, Limnol. Oceanogr., 34, 1545-1562, 1989.

Morel, A. and Maritorena, S.: Bio-optical properties of oceanic waters: a reappraisal, J. Geophys. Res.-Oceans, 106, 7163-7180, https://doi.org/10.1029/2000jc000319, 2001.

Myriokefalitakis, S., Vignati, E., Tsigaridis, K., Papadimas, C., Sciare, J., Mihalopoulos, N., Facchini, M. C., Rinaldi, M., Dentener, F. J., Ceburnis, D., Hatzianastasiou, N., O’Dowd, C. D., van Weele, M., and Kanakidou, M.: Global modeling of the oceanic source of organic aerosols, Adv. Meteorol., 16, 939171, https://doi.org/10.1155/2010/939171, 2010.

Nightingale, P. D., Liss, P. S., and Schlosser, P.: Measurements of air-sea gas transfer during an open ocean algal bloom, Geophys. Res. Lett., 27, 2117-2120, https://doi.org/10.1029/2000gl011541, 2000.

Ooki, A., Nomura, D., Nishino, S., Kikuchi, T., and Yokouchi, Y.: A global-scale map of isoprene and volatile organic iodine in surface seawater of the Arctic, Northwest Pacific, Indian, and 
Southern Oceans, J. Geophys. Res.-Oceans, 120, 4108-4128, https://doi.org/10.1002/2014JC010519, 2015.

Palmer, P. I. and Shaw, S. L.: Quantifying global marine isoprene fluxes using MODIS chlorophyll observations, Geophys. Res. Lett., 32, L09805, https://doi.org/10.1029/2005g1022592, 2005.

Rinnan, R., Steinke, M., McGenity, T., and Loreto, F.: Plant volatiles in extreme terrestrial and marine environments, Plant Cell Environ., 37, 1776-1789, https://doi.org/10.1111/pce.12320, 2014.

Schott, F. A., Xie, S.-P., and McCreary, J. P.: Indian Ocean circulation and climate variability, Rev. Geophys., 47, RG1002, https://doi.org/10.1029/2007RG000245, 2009.

Shaw, S. L., Chisholm, S. W., and Prinn, R. G.: Isoprene production by Prochlorococcus, a marine cyanobacterium, and other phytoplankton, Mar. Chem., 80, 227-245, https://doi.org/10.1016/S0304-4203(02)00101-9, 2003.

Shaw, S. L., Gantt, B., and Meskhidze, N.: Production and emissions of marine isoprene and monoterpenes: a review, Adv. Meteorol., 408696, https://doi.org/10.1155/2010/408696, 2010.

Shenoy, D. M., Kumar, M. D., and Sarma, V.: Controls of dimethyl sulphide in the Bay of Bengal during BOBMEX-Pilot cruise 1998, P. Indian AS-Earth, 109, 279-283, 2000.

Spracklen, D. V., Arnold, S. R., Sciare, J., Carslaw, K. S., and Pio, C.: Globally significant oceanic source of organic carbon aerosol, Geophys. Res. Lett., 35, 5, https://doi.org/10.1029/2008g1033359, 2008.

Srikanta Dani, K. G., Silva Benavides, A. M., Michelozzi, M., Peluso, G., Torzillo, G., and Loreto, F.: Relationship between isoprene emission and photosynthesis in diatoms, and its implications for global marine isoprene estimates, Mar. Chem., 189, 17-24, https://doi.org/10.1016/j.marchem.2016.12.005, 2017.

Stramma, L., Fischer, T., Grundle, D. S., Krahmann, G., Bange, H. W., and Marandino, C. A.: Observed El Niño conditions in the eastern tropical Pacific in October 2015, Ocean Sci., 12, 861873, https://doi.org/10.5194/os-12-861-2016, 2016.

Surratt, J. D., Chan, A. W. H., Eddingsaas, N. C., Chan, M. N., Loza, C. L., Kwan, A. J., Hersey, S. P., Flagan, R. C., Wennberg, P. O., and Seinfeld, J. H.: Reactive intermediates revealed in secondary organic aerosol formation from isoprene, P. Natl. Acad. Sci. USA, 107, 6640-6645, https://doi.org/10.1073/pnas.0911114107, 2010.
Taylor, B. B., Torrecilla, E., Bernhardt, A., Taylor, M. H., Peeken, I., Röttgers, R., Piera, J., and Bracher, A.: Bio-optical provinces in the eastern Atlantic Ocean and their biogeographical relevance, Biogeosciences, 8, 3609-3629, https://doi.org/10.5194/bg-83609-2011, 2011.

Tran, S., Bonsang, B., Gros, V., Peeken, I., Sarda-Esteve, R., Bernhardt, A., and Belviso, S.: A survey of carbon monoxide and nonmethane hydrocarbons in the Arctic Ocean during summer 2010, Biogeosciences, 10, 1909-1935, https://doi.org/10.5194/bg-101909-2013, 2013.

Uitz, J., Claustre, H., Morel, A., and Hooker, S. B.: Vertical distribution of phytoplankton communities in open ocean: an assessment based on surface chlorophyll, J. Geophys. Res.-Oceans, 111, C08005, https://doi.org/10.1029/2005JC003207, 2006.

Unrein, F., Gasol, J. M., Not, F., Forn, I., and Massana, R.: Mixotrophic haptophytes are key bacterial grazers in oligotrophic coastal waters, ISME J., 8, 164-176, https://doi.org/10.1038/ismej.2013.132, 2014.

Vidussi, F., Claustre, H., Manca, B. B., Luchetta, A., and Marty, J.C.: Phytoplankton pigment distribution in relation to upper thermocline circulation in the eastern Mediterranean Sea during winter, J. Geophys. Res.-Oceans, 106, 19939-19956, https://doi.org/10.1029/1999JC000308, 2001.

Wanninkhof, R.: Relationship between wind speed and gas exchange over the ocean, J. Geophys. Res.-Oceans, 97, 7373-7382, https://doi.org/10.1029/92JC00188, 1992.

Wanninkhof, R. and McGillis, W. R.: A cubic relationship between air-sea $\mathrm{CO}_{2}$ exchange and wind speed, Geophys. Res. Lett., 26, 1889-1892, https://doi.org/10.1029/1999g1900363, 1999.

Zindler, C., Marandino, C. A., Bange, H. W., Schütte, F., and Saltzman, E. S.: Nutrient availability determines dimethyl sulfide and isoprene distribution in the eastern Atlantic Ocean, Geophys. Res. Lett., 41, 3181-3188, https://doi.org/10.1002/2014GL059547, 2014. 